Review

\title{
A comprehensive review of heregulins, HER3, and HER4 as potential therapeutic targets in cancer
}

\author{
Jose Mauricio Mota ${ }^{1}$, Katharine Ann Collier ${ }^{3}$, Ricardo Lima Barros Costa ${ }^{2}$, Timothy \\ Taxter $^{2}$, Aparna Kalyan², Caio A. Leite ${ }^{4}$, Young Kwang Chae ${ }^{2}$, Francis J. Giles ${ }^{2}$ and \\ Benedito A. Carneiro² \\ ${ }^{1}$ Instituto do Câncer do Estado de São Paulo, Division of Oncology, Universidade de São Paulo, São Paulo, Brazil \\ ${ }^{2}$ Developmental Therapeutics Program, Division of Hematology and Oncology, Feinberg School of Medicine, Northwestern \\ University, Chicago, Illinois, USA \\ ${ }^{3}$ Department of Medicine, Feinberg School of Medicine, Northwestern University, Chicago, Illinois, USA \\ ${ }^{4}$ Department of Pharmacology, Ribeirão Preto Medical School, University of São Paulo, São Paulo, Brazil \\ Correspondence to: Benedito A. Carneiro, email: benedito.carneiro@northwestern.edu
}

Keywords: heregulins, HER3, HER4, cancer, developmental therapeutics

Received: March 19, $2017 \quad$ Accepted: April 17, $2017 \quad$ Published: June 13, 2017

Copyright: Mauricio Mota et al. This is an open-access article distributed under the terms of the Creative Commons Attribution License 3.0 (CC BY 3.0), which permits unrestricted use, distribution, and reproduction in any medium, provided the original author and source are credited.

\section{ABSTRACT}

Heregulins (HRGs) bind to the receptors HER3 or HER4, induce receptor dimerization, and trigger downstream signaling that leads to tumor progression and resistance to targeted therapies. Increased expression of HRGs has been associated with worse clinical prognosis; therefore, attempts to block HRG-dependent tumor growth have been pursued. This manuscript summarizes the function and signaling of HRGs and review the preclinical evidence of its involvement in carcinogenesis, prognosis, and treatment resistance in several malignancies such as colorectal cancer, non-small cell lung cancer, ovarian cancer, and breast cancer. Agents in preclinical development and clinical trials of novel therapeutics targeting HRGdependent signaling are also discussed, including anti-HER3 and -HER4 antibodies, anti-metalloproteinase agents, and HRG fusion proteins. Although several trials have indicated an acceptable safety profile, translating preclinical findings into clinical practice remains a challenge in this field, possibly due to the complexity of downstream signaling and patterns of HRG, HER3 and HER4 expression in different cancer subtypes. Improving patient selection through biomarkers and understanding the resistance mechanisms may translate into significant clinical benefits in the near future.

\section{INTRODUCTION}

Heregulins (HRGs; aliases: neuregulin, Neu differentiation factor, glial growth factor, acetylcholine receptor-inducing activity) are growth factors that trigger multi-step kinase-dependent signaling events after binding to the transmembrane receptors HER3 or HER4. Deregulation of this pathway have been linked to several conditions including schizophrenia, heart failure, atherosclerosis, and cancer. Specifically in cancer, HRGs are implicated in stemness, invasiveness, proliferation, resistance to apoptosis, and angiogenesis. $[1,2]$ This manuscript summarizes the role of HRGs in carcinogenesis and advances in the development of novel therapies targeting HRG-mediated pathways.

\section{HEREGULIN STRUCTURE SIGNALING MECHANISM}

AND

A 44-kDa glycoprotein, later to be classified as an HRG, was isolated and cloned from RAS-transformed rat fibroblasts in 1992.[3] The protein named Neu differentiation factor induced phosphorylation of $\mathrm{p} 185^{\text {neu }}$ (later called HER2/neu) and differentiation of human breast cancer cells.[3] Almost concomitantly, another group purified and cloned a $45-\mathrm{kDa}$ protein from a human breast cell line that induced phosphorylation of $\mathrm{p} 185^{\text {neu/ }}$ HER2, which they named HRG.[4]

Four major types of HRG proteins have been described: HRG-1 (subdivided in type I, II and III), HRG-2, HRG-3 and HRG-4. Alternate splicing of the 
four genes results in at least 26 different isoforms with distinct binding affinities to the HER family of receptors. [1] The protein structure is comprised of an N-terminus motif, an Ig-like domain (HRG-1 types I and II and HRG-2), an EGF-like domain, a juxtamembrane domain, a transmembrane domain, and a cytoplasmic tail. The proteins are synthesized as large membrane-anchored glycosylated precursors, with the EGFR-like motif positioned in the extracellular compartment.

HRGs were thought to be HER2 ligands since they cause phosphorylation of HER2. However, they were incapable of stimulating tyrosine kinase phosphorylation in fibroblasts overexpressing HER2.[5] Rather, it was shown that the HRGs interact with HER3 and HER4, but do not bind to HER2 receptors.[6] The extracellular EGF-like domain of HRG is essential for binding to and activation of HER3 in a juxtacrine fashion.[7] Furthermore, the HRG protein can be cleaved from the cellular membrane by metalloproteinases and result in paracrine or autocrine signaling.[8]

When HRG binds to HER3 or HER4, the dimerization arm is untethered, resulting in heterodimerization or homodimerization of HER3 or HER4 with HER4 or, preferentially, HER2.[9] HER3 does not homodimerize after HRG binding. Receptor dimerization activates tyrosine kinase activity, leading to trans-phosphorylation of the tyrosine-rich C-terminal region of HER3 or auto-phosphorylation of HER4. [1013] In the case of HER3/HER 2 dimerization, HER3, which is a kinase-dead receptor, does not phosphorylate HER2; rather, the dimerization results in a conformational change in HER2 resulting in activation of its downstream signaling. [14] The C-terminal phosphorylation motifs depend on the ligand isoform and different dimer combinations and, in turn, elicit different downstream signaling events. Therefore, the predominant types of HER present on the cell surface, in addition to the HRG isoform, affect downstream signaling that result in cell migration, proliferation, differentiation or apoptosis.[15]

Figure 1 depicts the how HRG elicits several intracellular pathways after binding to HER3 or HER4. HER3-mediated signaling involves the MAPK/ERK, $\mathrm{PI} 3 \mathrm{~K} / \mathrm{AKT} / \mathrm{MTOR}, \mathrm{JAK} / \mathrm{STAT}$, and PKC protein kinase pathways.[16] In general, HER3-containing heterodimers (i.e. HER2/HER3 and HER3/HER4) are tumor-promoting. [17] On the other hand, HER4-mediated signaling results in either pro-tumor or anti-tumor effects through multiple protein kinase pathways, including JAK/STAT and PI3K/AKT. HER4 activating mutations upregulate the PI3K/AKT pathway.[18] In cancer cells, HER4

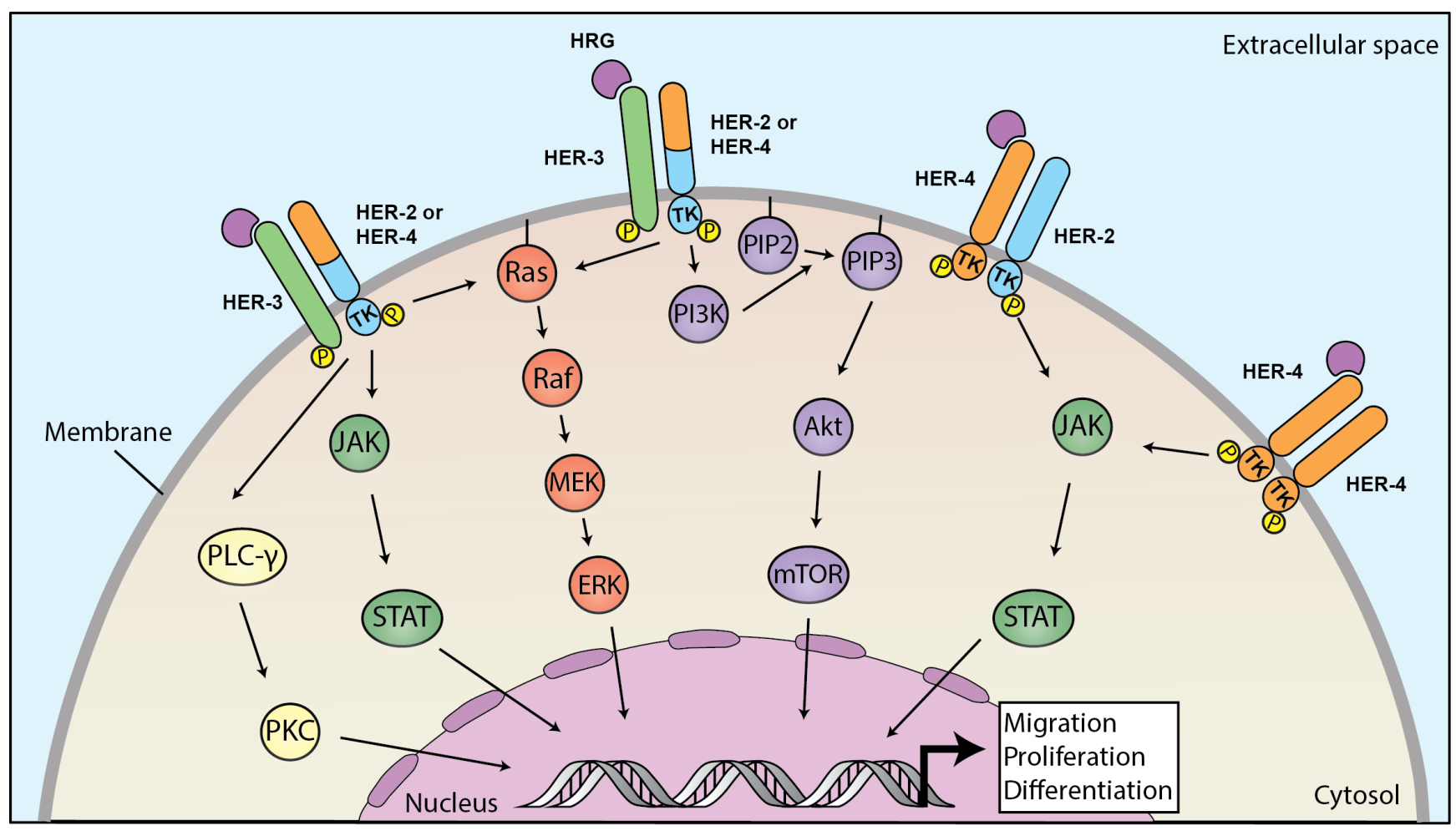

Figure 1: Heregulins bind to HER3 or HER4 to mediate downstream signaling linked to carcinogenesis. Binding of heregulin HER3 or HER4 triggers dimerization to HER2 or HER4 and phosphorylation of intracellular domains, leading to activation of downstream pathways. HER3-activated pathways involve MAPK/ERK, PI3K/AKT/MTOR, JAK/STAT and PKC and HER4 that promote proliferation, migration and differentiation of cancer cell. HER: human epithelial growth factor receptor; MAPK: mitogen-activated protein kinase; ERK: extracellular signal-regulated kinases; PI3K: phosphoinositide 3-kinase; AKT: protein kinase B; MTOR: mechanistic target of rapamycin; JAK: Janus kinase; STAT: signal transducer and activator of transcription; PKC: protein kinase C. 
promotes proliferation, invasion, and cell migration, or differentiation and apoptosis. [19-24] When HRG1 binds to HER4, juxtamembrane and intramembrane proteolysis causes release of a soluble intracellular domain, which relocates to the nucleus, activates YAP, and mediates transcription of YAP/HIPPO target genes involved with proliferation and apoptosis.[22]

Regulation of the HRG/HER signaling pathway occurs at many points. Competitive receptors such as p85-soluble-ErbB3 can trap HRG and prevent activation of HER2, HER3 and HER4.[25] In the case of or autocrine signaling, cleavage of the extracellular EGF-like domain from the HRG protein is dependent on metalloproteinases. Figure 2 illustrates how HRGs act in paracrine, juxtacrine and autocrine ways. The presence and activity of the metalloproteinases in turn control the amount of released HRG protein available to bind to HER receptors. For example, ADAM17, a disintegrin and metalloproteinase 17 , mediates motility and angiogenesis associated with colon cancer cells through neuregulin-1.[26] Any process modulating the expression of HER2, HER3, and HER4 on the cell surface alter the effect of HRG/HER signaling. For example, NEDD4 (neural precursor cell expressed developmentally downregulated-4), an E3 ubiquitin ligase, can reduce HER3 expression on the cell surface.[27]

\section{THE HEREGULINS-DEPENDENT PATHWAY IN DIFFERENT CANCER TYPES}

\section{Colorectal cancer (CRC)}

HRGs, HER3, and HER4 are implicated in CRC carcinogenesis. HRGs contribute to colonic carcinogenesis through increased cyclooxygenase-2 (COX-2) mRNA expression, PI3K/AKT-mediated proliferation and VEGFmediated angiogenesis and impaired apoptosis. Increased HER4 expression has been observed in all stages of colorectal carcinogenesis, including adenomas, but not in normal colonic mucosa.[28, 29]

HER3 mutations, detected in up to $11 \%$ of CRCs, are associated with malignant transformation in vitro. [30] HER4 overexpression was documented in $17 \%$ of CRC samples and mutations were detected in $2.9 \%$ of CRCs.[28, 31] HER3 and HER4 expression, as well as phosphorylated HER3 and HER4, were associated with worse prognosis.[32]

Preclinical experiments suggest that targeting HER3 ant the HRG/HER3 pathway can have therapeutic implications including mediating resistance to cetuximab (an anti-EGFR monoclonal antibody) and vemurafenib (a BRAF inhibitor) treatments. Anti-HER3 antibodies or genetic silencing of the HER3 gene reduces colon cancer cell proliferation, migration, and invasion.[33] HRGs and the heterodimer HER3/HER2 mediate the development of resistance to cetuximab in preclinical models. In metastatic CRC, patients with high amphiregulin and low HRG plasma levels have higher response rates to cetuximabbased therapies.[34] In BRAF-V600E mutant colon cancer stem cells (CSCs), HER3/Neuregulin-1 $\beta$ induces cellular proliferation and drug resistance to vemurafenib.[35]

\section{Non-small cell lung cancer (NSCLC)}

HER 2 and HER3 expression were found in 7\% and $32 \%$ of resected NSCLC tumors, respectively.[36] Neurotensin upregulation also occurs in $60 \%$ of NSCLCs and positively correlates with increased HER3 and HER2 expression.[37] Despite the lack of association between HRGs expression and prognosis in NSCLC, gene fusions involving NRG1 have been identified as drivers of NSCLCs (e.g. VAMP2-NRG1).[38, 39] The CD74-NRG1 gene fusion produces an EGF-like domain of NRG1 that can activate HER3/HER2.[40] In preclinical models, residual cells after chemotherapy have increased HRG1 expression and autocrine HER3 and HER4 pathway activation. Also, preclinical data suggest that increased expression of HER3 and NRG1 contribute to resistance to ALK inhibitors.[41-43] Although therapies to block HER2 in NSCLC have had disappointing results in the past, perhaps therapies directed at HRGs, HER3 or HER4 would be more successful. Anti-HER4 treatment has been shown to reduce recurrence after cessation of chemotherapy in the experimental scenario.[44]

\section{Head and neck squamous cell carcinoma (HNSCC)}

HNSCCs display one of the highest expression levels of HRG among different cancers with $40 \%$ of specimens expressing high levels of HRGs. HRGs mediate proliferation and invasion and are associated with worse prognosis.[45, 46] HER3 expression, present in $8.8 \%$ of HNSCCs, correlates with lower OS.[47] Trop2, a transmembrane protein that forms a complex with NRG-1 in the cytosol, reduces the amount of available NRG-1 available to participate in binding to HERs and plays an important role in regulating the HRG/HER3 pathway in HNSCC.[48, 49] HRG expression is higher in recurrent tumors than in primary tumors suggesting a role in treatment resistance.[50] NRG1 overexpression is associated with primary resistance to cisplatin, and siRNA-suppression of NRG1 reverses this effect.[51] Furthermore, increased NRG1 mRNA predicts response to cetuximab in vitro.[52] These results have fostered interest in targeting this pathway for HNSCC treatment. In vitro, HNSCCs respond to anti-HER3 antibodies, with 
increased response in Trop2 expressing cells.[49] Wilson et al. showed that a subset of HNSCC cell lines respond to lapatinib, a tyrosine kinase inhibitor of EGFR and HER2. Increased NRG1 and phosphorylated HER3 levels were associated with increased lapatinib sensitivity.[53]

\section{Prostate cancer}

NRG-4, HER3 and HER4 expression have been documented in a subset of prostrate cancers. [54] Prostate cancers that overexpress HER3 depend on its expression for malignant progression. [55] In prostate cancer, unlike in many other cancer types, high HRG expression is associated with favorable outcomes. In a cohort of 357 hormone-naïve prostate cancers, high membranous HRG expression was associated with better outcomes (increased time to relapse and OS) and fell significantly in post- relapse specimens.[56]

$\mathrm{HRG} / \mathrm{HER}$ signaling in prostate cancer is modulated by EBP-1, a HER3-binding protein, that reduces HRGinduced tumor growth and represses androgen receptors expression. EBP-1 levels are decreased in prostate cancer and restoring EBP-1 levels in a prostate cancer animal model decreases tumorigenicity.[57] EBP-1 expression may be decreased by post-transcriptional up-regulation of androgen receptors.[58]

The effect of HRGs on prostate cancer is hormone dependent. HRGs inhibit proliferation in hormone-naïve cells, whereas HRGs increase tumor proliferation in castration-resistant disease. Exposing hormone-naïve prostate cancer cells to HRGs reduces aneuploidy and proliferation.[59] On the other hand, in androgenindependent prostate cancer, activation of HER2/HER3 increases androgen receptor transactivation and tumor growth.[60]

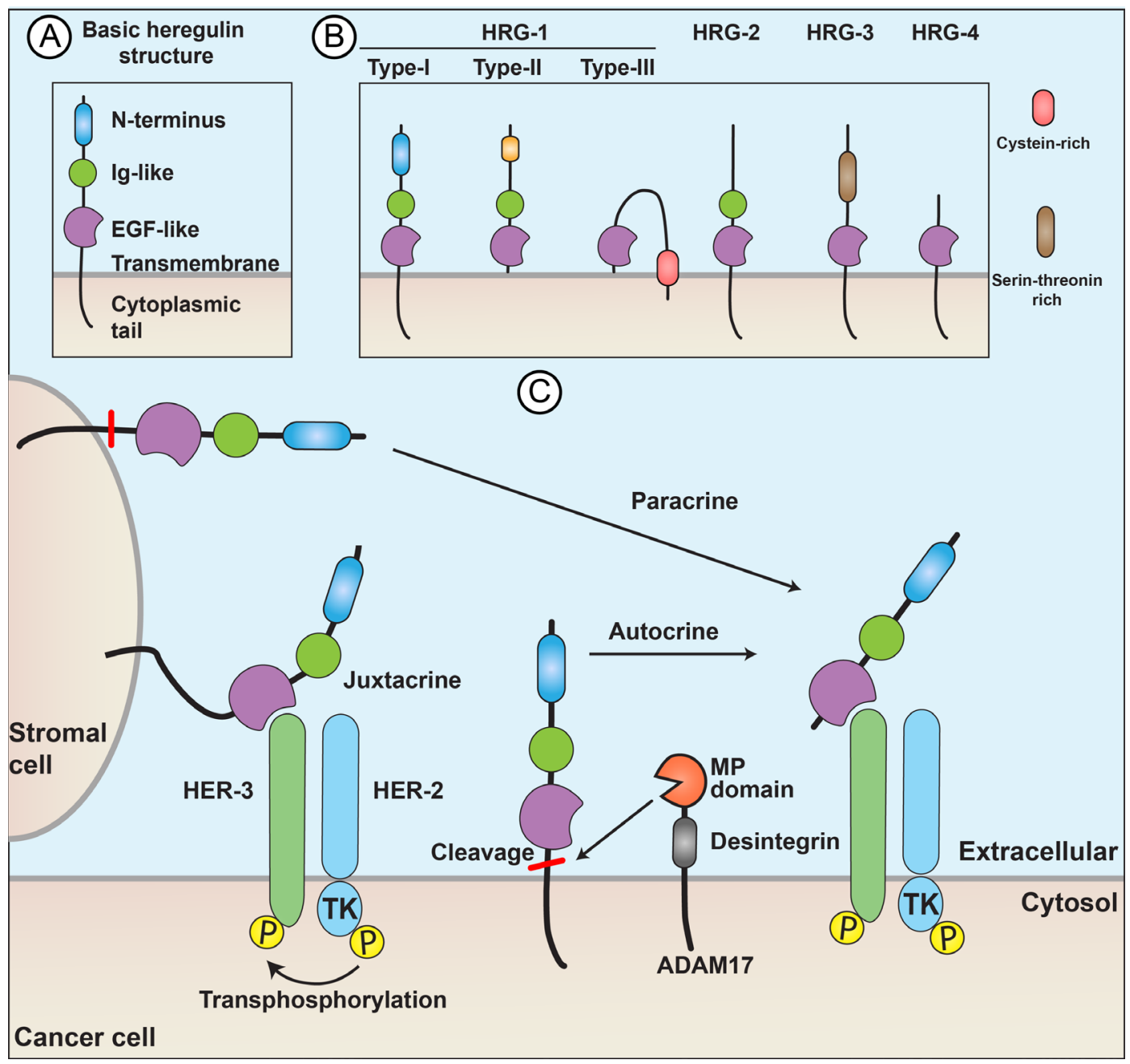

Figure 2: Heregulins act through paracrine, juxtacrine, or autocrine signaling. (A) The protein structure includes an N-terminus motif, an Ig-like domain (HRG-1 types I and II and HRG-2), an EGF-like domain a juxtamembrane domain a transmembrane domain (the most variable region among different HRG subtypes) and a cytoplasmic tail. (B) Basic structural differences of HRG subtypes. The EGF-like domain is highly conserved across species and is essential and sufficient for receptor binding and activation. (C) Paracrine, juxtacrine, and autocrine signaling. Autocrine and paracrine signaling depend on metalloproteinases, such as ADAM17, which cleave the HRG from cell membrane. 


\section{Ovarian cancer}

HER3 and HER4 are expressed in several different types of ovarian cancer. In ovarian epithelial adenocarcinomas, HER3 was detected in $53.4 \%$ of samples.[61] HER4 was detected in $89-95 \%$ of serous cystadenocarcinomas.[62] In granulosa cell tumors, HER4 expression was higher than HER 2 or HER3. NRG- $1 \alpha$ and NRG- $1 \beta$ were expressed in $87 \%$ and $77 \%$ of tumors, respectively, and were shown to regulate growth of tumor cell lines in vitro. [63]

The HRG/HER3 pathway has been implicated in resistance of ovarian epithelial adenocarcinomas to chemotherapy and targeted therapies. In doxorubicinresistant epithelial carcinoma cells, an anti-apoptotic signaling pathway depends on HER3 ligands, the metalloproteinase ADAM17, and HER2.[64] HER3 is downregulated in patients with poor or no response to chemotherapy.[65] Conversely, HER3 overexpression has been associated with acquired resistance to trastuzumab in ovarian epithelial adenocarcinomas.[66] In a phase II trial of patients with platinum-resistant ovarian epithelial carcinoma, low HER3 mRNA expression predicted response to gemcitabine plus an anti-HER2 antibody (pertuzumab).[67, 68] These results suggest therapeutic potential of the HRG/HER pathway in ovarian cancer treatment.

\section{Breast cancer}

HER3 is overexpressed in approximately $50 \%$ of breast cancers and confers a worse prognosis.[69-72] In HER2-amplified breast cancers, HER3 is the preferential partner for dimer formation.[73, 74] HER3 mutations are common in lobular invasive breast cancer.[75] HER4 has been reported as downregulated in $18-75 \%$ of breast cancers and upregulated in 7-29\% of cases.[76] HER4 expression and the expression of its intracellular domain correlate with luminal and well-differentiated histology, expression of estrogen and progesterone-receptors, low histological grade, low Ki67, tamoxifen-responsiveness, and possibly better clinical outcomes.[76-79] However, nuclear HER4 is linked to poor outcomes in HER2+ breast cancers. [80]

HRGs through HER3 or HER4-mediated signaling participate in the embryonic development of mammary gland.[81-83] HRGs are expressed in the cytoplasm as well as in the nucleus of human breast cancer cells. There are no differences in NRG2 expression between HER2positive and HER2-negative breast cancers. However, $N R G 2$ median expression is increased up to three-fold in estrogen receptor (ER) and progesterone receptor (PR) negative tumors compared to ER- and PR-positive samples.[84] A different study found expression of HER3 ligands (NRG1 and NRG2) in $39.3 \%$ of samples and
HER4 ligands (NRG1-4, EREG, BTC, HB-EGF) in 74.1\% of samples.[84] Rearrangements in the NRG1 gene were found in 17 of 382 of breast cancer cases, and an amplicon centromeric to NRG1 was found in 63 of 262 cases and correlated with poor prognosis.[85] NRG expression has been associated with both better and worse prognosis. In breast cancer cell lines, overexpression of HRG induces a more aggressive, hormone-independent phenotype with increased angiogenesis and stemness properties. [86-90] HRG overexpression also promotes cell motility, metastasis, and invasiveness. Furthermore, in breast cancer cells, NRG-2 $\beta$ was shown to promote telomere shortening, inducing chromosomal instability.[91] NRG$1 \beta$ expression in breast cancer stromal cells correlated with a worse prognosis.[92] Also, NRG-2 $\beta$ and NRG4 correlated with high-grade tumors.[93] On the other hand, in a cohort of 115 breast cancer patients, NRG-1 $\alpha$ expression was present in $84 \%$ of samples and correlated with a better prognosis.[94] NRG-3 nuclear staining also correlated with low-grade tumors.[92]

The precise role of HER4 in breast cancer carcinogenesis remains not fully understood. HER4 mediates both protumoral and antiproliferative and proapoptotic signals in breast cancer cells. [76]

HER3 overexpression predicts resistance to trastuzumab, though HER3 expression has not been shown as a predictive factor in combination treatment of trastuzumab and pertuzumab in HER2+ breast cancers. [95] HER2-positive cells also acquire resistance to trastuzumab through increased ADAM10-mediated HRG release.[96] HER3 overexpression also correlates with resistance to lapatinib. HRG expression may predict clinical response to trastuzumab in breast cancer without HER2 amplification and can mediate acquired resistance to lapatinib.[97, 98] NRG-Beta1 mediates trastuzumab emtansine resistance and treatment with pertuzumab circumvents this issue.[99]

Limited data are available for other histologies such as pancreatic cancer, thyroid cancers, small cell lung cancer, bladder cancer and sarcomas.

\section{TARGETING HEREGULIN-DEPENDENT SIGNALING}

Figure 3 summarizes therapeutics targeting HRGdependent signaling, including anti-HER3, anti-HER4, bispecific antibodies and HRG fusion proteins.

\section{Anti-HER3 antibodies}

Patritumab (U3-1287 or AMG-888) is a fully humanized antibody to HER 3 that impairs HRG binding. In models of HNSCC and lung cancer, patritumab enhanced radiosensitivity.[100] In CRC and NSCLC cell lines and animal models, patritumab reversed resistance to anti-EGFR treatment with cetuximab.[101, 102] In 
NSCLC cell lines and mouse models, patritumab also improved response to the EGFR tyrosine kinase inhibitor erlotinib. Uveal melanoma cells overcame resistance to MEK inhibitors when treated with patritumab.[103]

The first clinical trial of patritumab (NCT00730470) enrolled 57 patients with advanced solid tumors including 29 patients with CRC and 20 patients with NSCLC. The most commonly observed toxicities were fatigue $(21.1 \%)$, diarrhea $(12.3 \%)$, and nausea (10.5\%), with only $1.8 \%$ incidence of grade 3 or higher adverse events.[104] Table 1 summarizes published and ongoing clinical trials evaluating patritumab.

Patritumab was also evaluated in combination with erlotinib for NSCLC, with cetuximab and platinumbased chemotherapy for HNSCC, and with trastuzumab and paclitaxel for HER2 positive breast cancer. A phase I study enrolled 24 Japanese patients with NSCLC after progression on first-line chemotherapy. The patients were treated with patritumab $9 \mathrm{mg} / \mathrm{kg}$ and $18 \mathrm{mg} / \mathrm{kg}$ every 3 weeks in combination with erlotinib with no grade 3 toxicities.[105] The phase II HERALD trial randomized patients with platinum-resistant, EGFR wildtype, advanced or metastatic NSCLC to erlotinib with high dose patritumab, low dose patritumab or placebo. The subgroup of high HRG expressing tumors showed increased PFS and has supported an ongoing phase III trial (NCT02134015).[106, 107] Phase I (NCT02350712) and phase II (NCT02633800) studies are currently testing the combination of patritumab with cetuximab and platinumbased therapy for HNSCC.[108] A phase Ib/II trial is also evaluating the combination of patritumab, trastuzumab and paclitaxel in first-line treatment of HER2-amplified breast cancers (NCT01512199).

Seribantumab (MM-121 or SAR256212) is a fully human monoclonal antibody targeting HER3. [109] In preclinical models of lung cancer and HNSCC, seribantumab decreased HER3 phosphorylation. $[109,110]$ A preclinical animal model of ovarian cancer treated with seribantumab also showed decreased tumor growth.[111]

When combined with seribantumab, the EGFR targeted therapies gefitinib, erlotinib and cetuximab have shown enhanced and more sustained activity in preclinical models of NSCLC, pancreatic ductal adenocarcinoma and HNSCC. An EGFR mutant lung cancer cell line was re-sensitized to gefitinib by seribantumab.[109] A mouse model of lung cancer treated with cetuximab and seribantumab showed a durable response compared to cetuximab alone where resistance developed rapidly.[109] In cell lines and animal models of HNSCC, seribantumab combined with cetuximab showed more potent cell and tumor growth suppression by inhibiting activation of HER3, EGFR, PI3K/AKT and ERK.[110] Cetuximabresistant HNSCC models were found to have upregulation of HER3 and were more effectively treated with combined cetuximab and seribantumab than either antibody alone. [112] In HER2 + breast cancer cell lines, seribatumab enhanced the effect of paclitaxel and delayed the onset of resistance to and restored sensitivity to the aromatase inhibitor letrozole.[113, 114] Seribatumab also showed significant anti-tumor activity in trastuzumab-resistant HER2+ breast cancer cell lines and animal models.[115]

Phase I trials showed that seribantumab has

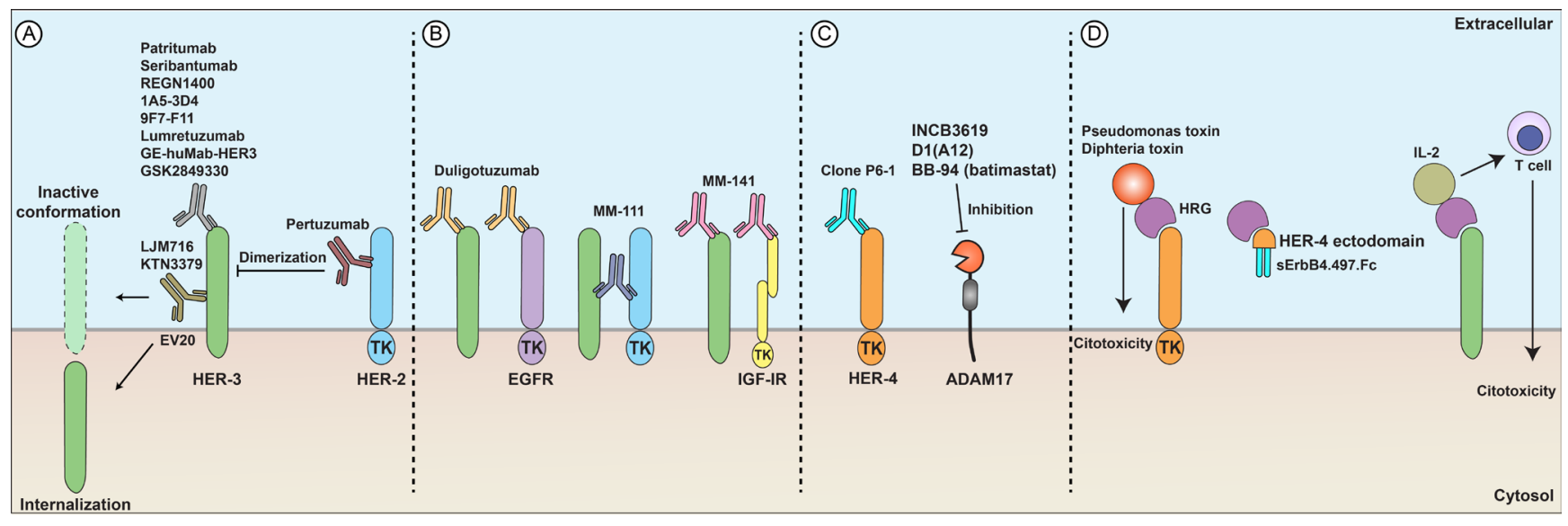

Figure 3: Developmental therapeutics and heregulins. (A) Anti-HER3 antibodies (patritumab, seribantumab, REGN1400) and anti-HER2 antibodies (pertuzumab) can block receptor dimerization, induce receptor internalization (EV20), or result in an inactive receptor conformation (LJM716 and KTN3379), subsequently impairing activation of downstream pathways and triggering antineoplastic responses. (B) Bispecific antibodies directed against HER3 and another growth factor receptor. Duligotuzumab binds to HER3 and EGFR; MM-111 binds to HER3 and HER2; MM-141 binds to HER3 and IGF-IR. (C) Anti-HER4 antibodies (clone P6-1) cause growth inhibition of breast cancer cells in vitro. ADAM17 inhibitors (batimastat, D1(A12), INCB3619) inhibit liberation of HRG from the cell surface and impair paracrine cell signaling. (D) HRG fusion proteins induce direct cytotoxicity (HRG plus Pseudomonas or diphteria toxin) or activate $T$ cells present in the tumor milieu (HRG plus IL-2). HER4 fusion proteins (HER4 ectodomain plus the human IgG Fc) trap HRGs, preventing their binding to functional receptors. 
Table 1: Patritumab (U3-1287 or AMG-888; Daiichi-Sankyo) mechanism of action, stage of development and specific study features.

\begin{tabular}{|c|c|c|c|c|c|}
\hline $\begin{array}{c}\text { Mechanism of } \\
\text { action }\end{array}$ & Stage & Ref & Identifier & Study features & Results \\
\hline \multirow{7}{*}{$\begin{array}{l}\text { anti-HER3; } \\
\text { impairs ligand- } \\
\text { dependent } \\
\text { signaling }\end{array}$} & Phase I & {$[104]$} & NCT00730470 & 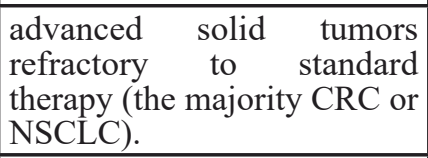 & $\begin{array}{l}\text { Safe at } 9 \text { to } 20 \mathrm{mg} / \mathrm{kg} \text { every } 2 \\
\text { to } 3 \text { weeks. AEs: fatigue and } \\
\text { diarrhea. }\end{array}$ \\
\hline & Phase I & {$[178]$} & NCT01957280 & $\begin{array}{l}\text { tested the safety and } \\
\text { pharmacokinetics of a new } \\
\text { patritumab formulation in } \\
\text { patients with solid tumors }\end{array}$ & $\begin{array}{l}\text { Safe at loading dose of } 18 \mathrm{mg} / \\
\mathrm{kg} \text { and maintenance dose of } \\
9 \mathrm{mg} / \mathrm{kg} \text {; AEs: diarrhea; no } \\
\text { HAHA formation }\end{array}$ \\
\hline & $\begin{array}{l}\text { Phase Ib/ } \\
\text { Phase II }\end{array}$ & [179] & NCT01512199 & $\begin{array}{l}\text { HER2+ metastatic breast } \\
\text { cancer; combination with } \\
\text { paclitaxel and trastuzumab }\end{array}$ & $\begin{array}{l}\text { Safe at } 9 \text { and } 18 \mathrm{mg} / \mathrm{kg} \text {; } \\
\text { no dose-limiting toxicities } \\
\text { observed; AEs: diarrhea, } \\
\text { alopecia and leukopenia }\end{array}$ \\
\hline & Phase I & - & NCT02350712 & $\begin{array}{l}\text { HNSCCs; combination with } \\
\text { cetuximab and platinum } \\
\text { containing therapy }\end{array}$ & completed, not published \\
\hline & Phase II & {$[108]$} & NCT02633800 & $\begin{array}{l}\text { HNSCCs; combination with } \\
\text { cetuximab and platinum } \\
\text { containing therapy }\end{array}$ & ongoing \\
\hline & $\begin{array}{l}\text { Phase I/ } \\
\text { Phase II }\end{array}$ & {$[106]$} & NCT01211483 & $\begin{array}{l}\text { platinum-resistant EGFR } \\
\text { WT advanced or metastatic } \\
\text { NSCLC; combination with } \\
\text { erlotinib; }\end{array}$ & $\begin{array}{l}\text { improved PFS in HRG-high, } \\
\text { but not in the intention-to- } \\
\text { treat population; AEs: rash and } \\
\text { diarrhea }\end{array}$ \\
\hline & Phase III & - & NCT02134015 & $\begin{array}{l}\text { platinum-resistant EGFR } \\
\text { WT advanced or metastatic } \\
\text { NSCLC; combination with } \\
\text { erlotinib; HER3-Lung study }\end{array}$ & ongoing \\
\hline
\end{tabular}

AEs: reported adverse events; HAHA: human-anti-human antibodies; CRC: colorectal cancer; NSCL: non small cell lung cancer; HNSCC: head and neck squamous cell carcinoma; HRG: heregulins; PFS: progression free survival.

a favorable toxicity profile as a single agent and in combination with chemotherapy or anti-EGFR and PI3K inhibitors.[116-118] A phase II trial evaluated the combination of exemestane $+/$ - seribantumab in postmenopausal women with advanced ER- and/or PRpositive HER2-negative breast cancer (NCT01151046). The trial showed no significant effect on the primary outcome of PFS, but suggested a possible increase in OS, specifically in patients with HRG-positive tumors. [119] A randomized phase II trial (NCT01421472) studied neoadjuvant paclitaxel $+/$ - seribantumab prior to doxorubicin and cyclophosphamide for locally advanced hormone-receptor-positive and triple negative breast cancer. Samples were evaluated for pathological compete response. Overall, the addition of seribantumab showed no significant benefit, but there was a trend toward higher pathologic complete response $(10.6 \%, 95 \%$ CI $[5.2 \%$, $20.3 \%$ vs. $3.3 \%, 95 \%$ CI $[0.6 \%, 16.7 \%])$ in patients with hormone-receptor-positive breast cancer, but not in patients with triple-negative tumors.[120]

A phase II trial (NCT01447706) evaluating paclitaxel $+/$ - seribantumab in platinum-resistant ovarian cancer demonstrated improved PFS in tumors positive for HRG, betacellulin (an EGFR ligand), HER2, HER3, or EGFR.[121] A phase II trial of erlotinib +/- seribantumab in patients with platinum-resistant, TKI-naïve, wild-type EGFR NSCLC showed no PFS or OS benefit.[122] The phase II SHERLOC trial of chemotherapy (docetaxel or pemetrexed) $+/$ - seribantumab in heregulin positive NSCLC is ongoing (NCT02387216). Despite encouraging results in preclinical models using seribantumab, phase II studies published to date have not shown clinical benefit in general patient populations. However, subgroup analyses from breast and ovarian cancer trials suggest that improving patient selection (i.e. HRGs positive tumors) may translate into significant results but will require confirmation in larger cohorts as well as validation of methods to measure HRGs expression in distinct clinical settings. Additional studies targeting the HRG pathway using seribantumab in this specific population are ongoing in other diseases, as depicted in Table 2.

LJM716 (Table 3) is an anti-HER3 antibody that traps HER3 in an inactive conformation and inhibits ligand-dependent and independent activation.[123] In HER2+ breast and gastric cancer cell lines and xenografts, decreased growth was seen after treatment with LJM716 alone and in combination with lapatinib/trastuzumab or alpelisib, a PI3K inhibitor.[124] Phase I studies have shown that LJM716 is safe and well tolerated in advanced solid tumors (NCT01598077, NCT01911936).[125, 126] A 
Table 2: Seribantumab (MM-121; Merrimack) mechanism of action, stage of development and specific study features.

\begin{tabular}{|c|c|c|c|c|c|}
\hline $\begin{array}{l}\text { Mechanism of } \\
\text { action }\end{array}$ & Stage & Ref & Identifier & Study features & Results \\
\hline \multirow{11}{*}{$\begin{array}{l}\text { anti-HER3; } \\
\text { impairs ligand- } \\
\text { dependent } \\
\text { signaling }\end{array}$} & Phase I & {$[117]$} & NCT01451632 & $\begin{array}{l}\text { advanced solid tumors; } \\
\text { with cetuximab +/- } \\
\text { irinotecan }\end{array}$ & $\begin{array}{l}\text { AEs: diarrhea, hypokalemia, } \\
\text { nausea, fatigue, rash }\end{array}$ \\
\hline & Phase I & - & NCT01436565 & $\begin{array}{l}\text { in advanced solid } \\
\text { tumors; with anti-PI3K } \\
\text { (piralarisib) }\end{array}$ & completed, not published \\
\hline & Phase I & - & NCT01209195 & $\begin{array}{l}\text { advanced gynecologic } \\
\text { or breast cancer; with } \\
\text { paclitaxel }\end{array}$ & completed, not published \\
\hline & Phase I & - & NCT02538627 & $\begin{array}{l}\text { mCRC, NSCLC, } \\
\text { HNSCC; with MM-151 } \\
\text { (anti-EGFR) }\end{array}$ & ongoing \\
\hline & Phase I & - & NCT00734305 & $\begin{array}{l}\text { advanced refractory } \\
\text { solid tumors; alone }\end{array}$ & ongoing \\
\hline & Phase I & {$[116]$} & NCT01447225 & $\begin{array}{l}\text { advanced solid tumors; } \\
\text { with chemotherapy }\end{array}$ & $\begin{array}{l}\text { AEs: diarrhea, nausea, fatigue, } \\
\text { anemia, hypokalemia, vomiting. }\end{array}$ \\
\hline & Phase I/II & {$[122]$} & NCT00994123 & $\begin{array}{l}\text { platinum-resistant } \\
\text { NSCLC; with erlotinib }\end{array}$ & $\begin{array}{l}\text { MM-121 was tolerated at } 20 \mathrm{mg} / \\
\mathrm{kg} \text { every other week; combination } \\
\text { was not effective in prolonging } \\
\text { PFS }\end{array}$ \\
\hline & Phase IIR & - & NCT02387216 & $\begin{array}{lr}\text { heregulin } & \text { positive } \\
\text { NSCLC; } & \text { with } \\
\text { chemotherapy; } & \\
\end{array}$ & ongoing \\
\hline & Phase II & {$[180]$} & NCT01151046 & $\begin{array}{l}\text { hormone receptor- } \\
\text { positive HER2-negative } \\
\text { advanced breast cancer; } \\
\text { with exemestane }\end{array}$ & $\begin{array}{l}\text { Combination of MM-121 and } \\
\text { exemestane did not prolong } \\
\text { PFS; prolonged PFS in patients } \\
\text { positive for two of pre-specified } \\
\text { biomarkers (HRG, betacellulin, } \\
\text { EGFR, HER2 and HER3), }\end{array}$ \\
\hline & Phase II & {$[121]$} & NCT01447706 & $\begin{array}{l}\text { platinum-resistant } \\
\text { EOC; with paclitaxel }\end{array}$ & $\begin{array}{l}\text { Combination with MM-121 did } \\
\text { not prolong PFS; prolonged PFS } \\
\text { in biomarker-guided population }\end{array}$ \\
\hline & Phase IIR & {$[120]$} & NCT01421472 & $\begin{array}{l}\text { TNBC or } \mathrm{HR}+\text { breast } \\
\text { cancer; with paclitaxel; } \\
\text { preoperative setting }\end{array}$ & $\begin{array}{l}\text { MM- } 121 \text { increased complete } \\
\text { pathologic response in HR+ group } \\
(10.6 \% \text { vs } 3.3 \%)\end{array}$ \\
\hline
\end{tabular}

AEs: adverse events; CRC: colorectal cancer; NSCL: non small cell lung cancer; HNSCC: head and neck squamous cell carcinoma; EOC: epithelial ovarian cancer; TNBC: triple negative breast cancer; HRG: heregulins; PFS: progression free survival.

phase I study (NCT01602406) of LJM716 in combination with trastuzumab in patients with advanced HER2-positive breast or gastric cancer demonstrated safety and provided preliminary efficacy results with $40 \%$ of patients achieving stable disease.[127] Additional trials are investigating the safety of LJM716 in combination with PI3K inhibitors and trastuzumab (NCT01822613, NCT02167854).[128]

REGN1400, (Table 4) an anti-HER3 antibody, increased sensitivity to anti-EGFR treatment in HNSCC in xenografts models.[129] A clinical trial showed that REGN1400 is safe and well tolerated alone or in combination with erlotinib or cetuximab in patients with advanced CRC, HNSCC and NSCLC (NCT01727869). [130]

KTN3379 (Table 3) is an anti-HER3 monoclonal antibody that binds to an epitope that locks HER3 in its inactive conformation and inhibits both ligand-dependent and ligand-independent signaling.[131] Preclinical data show that the anti-tumor effects of KTN3379 were attenuated in PTEN-knockdown tumor cell lines.[132] A phase I study (NCT02014909) has proven safety of KTN3379 alone or in combination with cetuximab, erlotinib, vemurafenib or trastuzumab in patients with advanced solid tumors.[133]

Av-203 (Table 5) is an IgG1k humanized antiHER3 monoclonal antibody that inhibits tumor growth in human cancer models with the level of NRG1 expression predictive of response.[134] A phase I clinical trial in patients with advanced solid tumors, including CRC, NSCLC, and HNSCC, showed that Av-203 is safe and well tolerated below a maximum dose of $20 \mathrm{mg} / \mathrm{kg}$ every 2 weeks.[135] One patient with NSCLC had a partial 
Table 3: LJM716 and KTN3379 mechanism of action, stage of development and specific study features

\begin{tabular}{|c|c|c|c|c|c|c|}
\hline Antibody & $\begin{array}{c}\text { Mechanism } \\
\text { of action }\end{array}$ & Stage & Ref & Identifier & Study features & Results \\
\hline \multirow{6}{*}{$\begin{array}{l}\text { LJM716 } \\
\text { Novartis }\end{array}$} & \multirow{6}{*}{$\begin{array}{l}\text { anti-HER3; } \\
\text { impairs } \\
\text { ligand- } \\
\text { dependent } \\
\text { and ligand- } \\
\text { independent } \\
\text { signaling }\end{array}$} & Phase I & [181] & NCT01911936 & $\begin{array}{l}\text { advanced solid tumors; in } \\
\text { Japanese patients }\end{array}$ & $\begin{array}{l}\text { well tolerated at } 10 \text { to } 40 \\
\mathrm{mg} / \mathrm{kg} \text { once weekly; AEs: } \\
\text { diarrhea, fatigue, stomatitis, } \\
\text { pyrexia and paronychia }\end{array}$ \\
\hline & & Phase I & [125] & NCT01598077 & $\begin{array}{l}\text { advanced or metastatic } \\
\text { HNSCC or HER2+ breast or } \\
\text { gastric cancer }\end{array}$ & $\begin{array}{l}\text { Well tolerated in doses up } \\
\text { to } 40 \mathrm{mg} / \mathrm{kg} \text { once weekly; } \\
\text { AEs: diarrhea, hypokalemia, } \\
\text { asthenia, chills, infusion- } \\
\text { related reactions }\end{array}$ \\
\hline & & Phase I & - & NCT02143622 & $\begin{array}{l}\text { platinum refractory advanced } \\
\text { HNSCC; in combination with } \\
\text { cetuximab }\end{array}$ & $\begin{array}{l}\text { study was terminated prior } \\
\text { to enrollment }\end{array}$ \\
\hline & & Phase I & {$[127]$} & NCT01602406 & $\begin{array}{|lr|}\text { advanced } & \text { HER2-positive } \\
\text { breast or gastric } & \text { cancer; } \\
\text { combination } & \text { with } \\
\text { trastuzumab } & \\
\end{array}$ & $\begin{array}{l}\text { Safe at } 3 \text { to } 40 \mathrm{mg} / \mathrm{kg} \text { once } \\
\text { weekly; AEs: diarrhea, } \\
\text { nausea, fatigue and chills }\end{array}$ \\
\hline & & Phase I & [128] & NCT02167854 & $\begin{array}{l}\text { advanced HER2-positive } \\
\text { breast cancer; combination } \\
\text { with BYL719 (PI3K } \\
\text { inhibitor) and trastuzumab }\end{array}$ & $\begin{array}{l}\text { Safe at } 20 \mathrm{mg} / \mathrm{kg} \text { once } \\
\text { weekly in this combination; } \\
\text { gastrointestinal and } \\
\text { metabolic toxicities limited } \\
\text { drug delivery }\end{array}$ \\
\hline & & $\begin{array}{l}\text { Phase } \\
\text { I/Phase } \\
\text { II }\end{array}$ & - & NCT01822613 & $\begin{array}{ll}\text { refractory } & \text { esophageal } \\
\text { squamous cell } & \text { carcinoma; } \\
\text { combined with } & \text { BYL719 } \\
\text { (PI3K inhibitor) } & \\
\end{array}$ & completed, not published \\
\hline \multirow{2}{*}{$\begin{array}{l}\text { KTN3379 } \\
\text { Kolltan }\end{array}$} & \multirow{2}{*}{$\begin{array}{l}\text { anti-HER3; } \\
\text { impairs } \\
\text { ligand- } \\
\text { dependent } \\
\text { and ligand- } \\
\text { independent } \\
\text { signaling }\end{array}$} & Phase I & {$[133]$} & NCT02014909 & $\begin{array}{l}\text { refractory advanced SCCHN, } \\
\text { CRC, HNSCC, melanoma } \\
\text { and HER2 }+ \text { breast cancer; } \\
\text { alone or combined with } \\
\text { cetuximab, erlotinib, } \\
\text { vemurafenib and trastuzumab }\end{array}$ & $\begin{array}{l}\text { Safe at } 5 \text { to } 20 \mathrm{mg} / \mathrm{kg} \text { every } \\
3 \text { weeks; main side effects } \\
\text { were diarrhea, mucositis and } \\
\text { rash }\end{array}$ \\
\hline & & Phase I & - & NCT02473731 & $\begin{array}{l}\text { window-of-opportunity study } \\
\text { to evaluate downstream } \\
\text { molecular pathways to } \\
\text { identify potential tumor } \\
\text { response and resistance } \\
\text { mechanisms in HNSCC }\end{array}$ & ongoing \\
\hline
\end{tabular}

AEs: adverse events; CRC: colorectal cancer; NSCL: non small cell lung cancer; HNSCC: head and neck squamous cell carcinoma; HRG: heregulins

response.

Lumretuzumab (RG7116, RO5479599) is a glycoengineered anti-HER3 antibody, which impairs HRG binding to HER3 and induces antibody dependent cytotoxicity in preclinical models.[136] Efficacy has been demonstrated in experimental models of HNSCC.[137] A recent phase I study proved the safety of RG7116 in patients with HER3-positive advanced solid tumors and showed stable disease in $21.3 \%$ or patients and partial response in $23.7 \%$ of patients (Table 5).[138]

There are at least nine other anti-HER3 antibodies in development. 1A5-3D4 is an anti-HER3 antibody that in combination with trastuzumab has shown tumor size reduction in preclinical gastric cancer xenografts.[139] 9F7-F11 is an anti-HER3 antibody that induces apoptosis in cell lines by increasing HER3 ubiquitination and degradation through JNKdependent ITCH/AIP4 activation. In pancreatic cancer xenografts, 9F7-F11 induced tumor regression.[140] GE-huMab-HER3 is a glycoengineered anti-HER3 antibody that enhances antibody-dependent cellmediated cytotoxicity and increases antitumor effect compared to the non-glycoengineered variant of the antibody WT-huMab-HER3.[141] GSK2849330 is a glycoengineered anti-HER3 monoclonal antibody that increases both complement-mediated and antibody- 
Table 4: Duligotuzumab (MEHD7495A), REGN1400, and GSK2849330 mechanism of action, stage of development and specific study features

\begin{tabular}{|c|c|c|c|c|c|c|}
\hline Antibody & $\begin{array}{c}\text { Mechanism of } \\
\text { action }\end{array}$ & Stage & Ref & Identifier & Study features & Results \\
\hline \multirow{5}{*}{$\begin{array}{l}\text { Duligotuzumab } \\
\text { (MEHD7495A) } \\
\text { Genentech Inc }\end{array}$} & \multirow{5}{*}{$\begin{array}{c}\text { anti-HER3 and } \\
\text { anti-EGFR } \\
\text { bispecific } \\
\text { antibody }\end{array}$} & Phase I & {$[153]$} & NCT01207323 & $\begin{array}{l}\text { advanced solid } \\
\text { tumors }\end{array}$ & $\begin{array}{l}\text { well tolerated at } 1 \\
\text { to } 30 \mathrm{mg} / \mathrm{kg} \text { every } 2 \\
\text { weeks; AEs: diarrhea, } \\
\text { nausea, headache, } \\
\text { fever; } 2 \text { patients } \\
\text { (HNSCCs) had } \\
\text { radiologic responses }\end{array}$ \\
\hline & & Phase IIR & {$[155]$} & NCT01577173 & $\begin{array}{l}\text { platinum- } \\
\text { refractory HNSCC }\end{array}$ & $\begin{array}{l}\text { Did not improve } \\
\text { outcomes in } \\
\text { comparison to } \\
\text { cetuximab }\end{array}$ \\
\hline & & Phase IIR & {$[156]$} & NCT01652482 & $\begin{array}{l}\text { mCRC after } \\
\text { progression to } \\
\text { oxaliplatin-based } \\
\text { chemotherapy }\end{array}$ & $\begin{array}{c}\text { FOLFIRI + } \\
\text { MEHD7495A did not } \\
\text { improve outcomes } \\
\text { in comparison } \\
\text { to FOLFIRI + } \\
\text { cetuximab } \\
\end{array}$ \\
\hline & & Phase Ib & {$[154]$} & NCT01911598 & $\begin{array}{l}\text { HNSCC; in } \\
\text { combination with } \\
\text { chemotherapy }\end{array}$ & $\begin{array}{l}\text { Safe at } 1650 \mathrm{mg} / \mathrm{kg} \\
\text { every } 3 \text { weeks; main } \\
\text { side effects were } \\
\text { diarrhea, neutropenia } \\
\text { and fatigue }\end{array}$ \\
\hline & & Phase I & - & NCT01986166 & $\begin{array}{l}\text { locally advanced } \\
\text { or mCRC with } \\
\text { mutant KRAS; in } \\
\text { combination with } \\
\text { cobimetinib } \\
\end{array}$ & $\begin{array}{l}\text { completed, not } \\
\text { published }\end{array}$ \\
\hline $\begin{array}{l}\text { REGN1400 } \\
\text { Regeneron }\end{array}$ & $\begin{array}{l}\text { anti-HER3; } \\
\text { impairs ligand- } \\
\text { dependent } \\
\text { signaling }\end{array}$ & Phase I & {$[130]$} & NCT01727869 & $\begin{array}{c}\text { patients with } \\
\text { advanced } \\
\text { NSCLC, CRC or } \\
\text { HNSCC; alone } \\
\text { or in combination } \\
\text { with erlotinib or } \\
\text { cetuximab } \\
\end{array}$ & $\begin{array}{c}\text { well tolerated at } 3,10 \\
\text { and } 20 \mathrm{mg} / \mathrm{kg} \text { every } \\
2 \text { weeks; AEs: rash, } \\
\text { diarrhea, nausea, } \\
\text { hypomagnesemia }\end{array}$ \\
\hline \multirow[b]{2}{*}{$\begin{array}{l}\text { GSK2849330 } \\
\text { GlaxoSmithKline }\end{array}$} & \multirow[b]{2}{*}{$\begin{array}{l}\text { glycoengineered } \\
\text { anti-HER3 } \\
\text { antibody with } \\
\text { enhanced } \\
\text { ADCC and CDC } \\
\text { activities }\end{array}$} & Phase I & - & NCT01966445 & $\begin{array}{c}\text { advanced HER3- } \\
\text { positive solid } \\
\text { tumors } \\
\end{array}$ & ongoing \\
\hline & & Phase I & - & NCT02345174 & $\begin{array}{l}\text { advanced HER-3 } \\
\text { expressing solid } \\
\text { tumors; to evaluate } \\
\text { the uptake of } \\
\text { Zirconium- } \\
\text { 89-labeled- } \\
\text { GSK2849330 }\end{array}$ & $\begin{array}{l}\text { completed, not } \\
\text { published }\end{array}$ \\
\hline
\end{tabular}

AEs: adverse events; CRC: colorectal cancer; NSCL: non small cell lung cancer; HNSCC: head and neck squamous cell carcinoma; HRG: heregulins

dependent cell-mediated cytotoxicity (CDC).[142] Phase I studies of GSK2849330 are ongoing (NCT01966445, NCT02345174) (Table 4). EV20 is an humanized antiHER3 antibody, which interferes with ligand-dependent and independent signaling and causes internalization of HER3 in several cancer cell lines.[143] EV20 reversed resistance to vemurafenib in BRAF-V600E mutant colon cancer stem cells.[35] HuHER3-8 is an anti-HER3 antibody that, when combined with BRAF inhibitors, reduces tumor growth in melanoma xenografts with WT
BRAF [144] or V600E mutated BRAF. [145] LMAb3 is an anti-HER3 antibody that can reverse HRG-mediated acquired resistance to anti-HER2 agents in ovarian cancer. [146] SGP1 is an anti-HER3 antibody that impairs HRG binding to HER3 and enhances antitumor effects when combined with trastuzumab.[147] Ab6 is an anti-HER3 antibody that, when combined with trastuzumab, reverses resistance to PI3K inhibitors in prostate cancer cells.[148] 
Table 5: Lumretuzumab (RG7166 or RO5479599) and AV-203 mechanism of action, stage of development and specific study features

\begin{tabular}{|c|c|c|c|c|c|c|}
\hline Antibody & $\begin{array}{l}\text { Mechanism of } \\
\text { action }\end{array}$ & Stage & Ref & Identifier & Study features & Results \\
\hline \multirow{3}{*}{$\begin{array}{l}\text { Lumretuzumab } \\
\text { (RG7116 or } \\
\text { RO5479599) } \\
\text { Regeneron }\end{array}$} & \multirow{3}{*}{$\begin{array}{l}\text { anti-HER3; } \\
\text { impairs ligand- } \\
\text { dependent } \\
\text { signaling; } \\
\text { downregulates } \\
\text { membranous } \\
\text { HER3; potentiates } \\
\text { ADCC }\end{array}$} & Phase I & [138] & NCT01482377 & $\begin{array}{l}\text { HER3-positive } \\
\text { advanced solid tumors }\end{array}$ & $\begin{array}{c}\text { well tolerated at } 100 \\
\text { to } 2,000 \mathrm{mg} \text { every } \\
2 \text { weeks; common } \\
\text { toxicities were } \\
\text { diarrhea, fatigue, } \\
\text { decreased appetite; } \\
10 \text { patients had stable } \\
\text { disease }\end{array}$ \\
\hline & & Phase I & [182] & NCT02204345 & $\begin{array}{l}\text { advanced NSCLC of } \\
\text { squamous histology; } \\
\text { in combination with } \\
\text { carboplatin and } \\
\text { paclitaxel }\end{array}$ & $\begin{array}{c}\text { Safe at } 800 \mathrm{mg} \text { every } 2 \\
\text { weeks; AEs: diarrhea, } \\
\text { asthenia, neurotoxicity; } \\
3 \text { patients with } \\
\text { high HRG mRNA } \\
\text { expression had partial } \\
\text { responses }\end{array}$ \\
\hline & & Phase I & - & NCT01918254 & $\begin{array}{l}\text { HER3\&HER2-positive } \\
\text { metastatic breast } \\
\text { cancer; in combination } \\
\text { with paclitaxel and } \\
\text { pertuzumab }\end{array}$ & $\begin{array}{l}\text { completed, not } \\
\text { published. }\end{array}$ \\
\hline $\begin{array}{l}\text { AV-203 } \\
A V E O\end{array}$ & $\begin{array}{l}\text { anti-HER3; } \\
\text { impairs ligand- } \\
\text { dependent } \\
\text { and ligand- } \\
\text { independent } \\
\text { signaling }\end{array}$ & Phase I & [135] & NCT01603979 & $\begin{array}{l}\text { metastatic or advanced } \\
\text { solid tumors }\end{array}$ & $\begin{array}{l}\text { Safe at } 2 \text { to } 20 \mathrm{mg} / \\
\text { kg every } 2 \text { weeks; } \\
\text { AEs: diarrhea, } \\
\text { decreased appetite, } \\
\text { hypokalemia, dry skin, } \\
\text { hypomagnesemia and } \\
\text { pruritus; } 1 \text { patient with } \\
\text { squamous cell NSCLC } \\
\text { had a partial response } \\
\end{array}$ \\
\hline
\end{tabular}

AEs: adverse events; NSCL: non small cell lung cancer; HRG: heregulins

\section{Anti-HER4 antibodies}

Recently, Okazaki et al. showed that an anti-HER4 antibody (clone P6-1) resulted in growth inhibition of breast cancer cells in a three-dimensional extracellular matrix culture system.[19]

\section{Bispecific antibodies}

Antibodies have been developed that simultaneously target HER3 and another receptor including EGFR, HER2 or IGF-1R. Duligotuzumab (MEHD7945A) is a bispecific anti-HER3 and anti-EGFR antibody. In preclinical models, it was more effective at inhibiting EGFR and HER3 mediated signaling than monospecific anti-HER3 antibodies.[149] In animal models, duligotuzumab increased radiosensitivity in NSCLC and HNSCC, overcame resistance to EGFR inhibitors in HNSCC, and increased response to PI3K inhibitors in triple negative breast cancer.[150-152] A phase I clinical trial (NCT01207323) of single agent duligotuzumab in locally advanced or metastatic refractory epithelial tumors documented its safety profile and showed partial responses in 2 of 12 patients with HNSCC that expressed high levels of HRGs.[153] A phase Ib trial (NCT01911598) showed that duligotuzumab is safe in combination with chemotherapy in patients with recurrent or metastatic HNSCC.[154] A phase II study (NCT01577173) did not show improved outcomes in platium-refractory HNSCCs treated with duligotuzumab compared to those treated with cetuximab.[155] A phase II trial (NCT01652482) of patients with KRAS exon 2 wild-type mCRC with progression of disease after oxaliplatin-containing chemotherapy compared duligotuzumab plus FOLFIRI to cetuximab plus FOLFIRI with no significant improvement in clinical outcomes.[156] Table 4 compiles published and ongoing studies investigating duligotuzumab.

MM-111 is a bispecific antibody that forms a trimeric complex with HER3 and HER2, resulting in inhibition of HER3 signaling. In preclinical models of HER2 overexpressing tumors it has shown antitumor activity.[157] In phase I trials (NCT01097460, NCT01304784, NCT00911898), MM-111 was safe and 
Table 6: MM-111 and MM-141 mechanism of action, stage of development and specific study features

\begin{tabular}{|c|c|c|c|c|c|c|}
\hline Antibody & $\begin{array}{c}\text { Mechanism of } \\
\text { action }\end{array}$ & Stage & Ref & Identifier & Study features & Results \\
\hline \multirow{4}{*}{$\begin{array}{l}\text { MM-111 } \\
\text { Merrimack } \\
\text { Pharmaceuticals }\end{array}$} & \multirow{4}{*}{$\begin{array}{l}\text { binds to HER3 } \\
\text { and HER2 }\end{array}$} & Phase I & - & NCT01097460 & $\begin{array}{l}\text { advanced HER2 and } \\
\text { HRG-positive breast } \\
\text { cancer; combination with } \\
\text { trastuzumab }\end{array}$ & $\begin{array}{l}\text { completed, not } \\
\text { published }\end{array}$ \\
\hline & & Phase I & {$[158]$} & NCT01304784 & $\begin{array}{l}\text { advanced HER2-positive } \\
\text { cancers; combination } \\
\text { with multiple treatments }\end{array}$ & \begin{tabular}{l}
\multicolumn{3}{l}{ recommended } \\
phase 2 doses: \\
$20 \mathrm{mg} / \mathrm{kg}$ once a \\
week and $40 \mathrm{mg} /$ \\
$\mathrm{kg}$ every 3 weeks; \\
AEs: anemia, \\
diarrhea, stomatitis, \\
hypokalemia
\end{tabular} \\
\hline & & Phase I & - & NCT00911898 & $\begin{array}{l}\text { advanced HER2 and } \\
\text { HRG-positive cancers; } \\
\text { monotherapy }\end{array}$ & $\begin{array}{l}\text { completed, not } \\
\text { published }\end{array}$ \\
\hline & & Phase II & {$[159]$} & NCT01774851 & \begin{tabular}{l}
\multicolumn{2}{l}{ HER2-positive } \\
carcinomas of the \\
distal esophagus, \\
gastroesophageal \\
junction and stomach; \\
$\begin{array}{lr}\text { combination } \\
\text { paclitaxel with } \\
\text { trastuzumab }\end{array}$
\end{tabular} & $\begin{array}{l}\text { No significant } \\
\text { improvement of } \\
\text { PFS or OS }\end{array}$ \\
\hline \multirow{2}{*}{$\begin{array}{l}\text { MM-141 } \\
\text { Merrimack } \\
\text { Pharmaceuticals }\end{array}$} & \multirow{2}{*}{$\begin{array}{l}\text { Binds to HER3 } \\
\text { and IGF-IR, } \\
\text { preventing HRG } \\
\text { and IFG signaling }\end{array}$} & Phase I & {$[164]$} & NCT01733004 & $\begin{array}{l}\text { advanced and refractory } \\
\text { solid tumors }\end{array}$ & $\begin{array}{l}\text { Safe at } 6,12 \text { or } 20 \\
\mathrm{mg} / \mathrm{kg} \text { once a week, } \\
\text { or at biweekly } \\
40 \mathrm{mg} / \mathrm{kg} ; \text { main } \\
\text { toxicities were } \\
\text { vomiting, fatigue } \\
\text { and abdominal pain }\end{array}$ \\
\hline & & Phase II & - & NCT02399137 & $\begin{array}{l}\text { metastatic pancreatic } \\
\text { adenocarcinoma; first- } \\
\text { line treatment combined } \\
\text { with gemcitabine and } \\
\text { nab-paclitaxel }\end{array}$ & ongoing \\
\hline
\end{tabular}

AEs: adverse events; HRG: heregulins

well tolerated.[158] A phase II trial NCT01774851), however, did not show any benefit in combining MM111 with paclitaxel plus trastuzumab in HER2 expressing gastroesophageal cancers (Table 6). These results were possibly related to lower than anticipated HRG expression in the patient population.[159] A possible strategy to improve clinical benefits of dual targeting EGFR and HER3 is to limit inclusion to tumors with high expression of HER3 and/or HRGs.

MM-141 is a bispecific tetravalent antibody to HER3 and IGF-1R. IGF-1R signaling activates the PI3K/AKT survival pathway and is involved in resistance to EGFR and HER2 inhibitors.[160, 161] Likewise, resistance to anti-IGF-1R therapies is mediated by HER3/HRG signaling.[162] In fact, MM-141 overcame resistance to anti-IGF-1R therapies and improved anti-tumor responses in preclinical models.[163] The safety profile of MM-141 was established in a phase I trial and an ongoing study is evaluating combination with gemcitabine and nabpaclitaxel in metastatic pancreatic cancer (NCT02399137)
(Table 6).[164]

\section{Anti-metalloproteinase agents}

Anti-metalloproteinase agents have shown promise in the preclinical setting. INCB3619, a specific ADAM17 metalloproteinase inhibitor, blocked HER3 signaling in gefitinib-resistant NSCLC cell lines.[165] D1(A12), another ADAM17 inhibitor, decreased protumor signaling in HNSCC and ovarian cancer models. [48, 166] Batimastat (BB-94), a broad spectrum antimetalloproteinase, prevented HER3 phosphorylation and Erk activation in fulvestrant-resistant breast cancer cell lines in a mechanism independent of ADAM17, suggesting potential therapeutic application in breast cancer.[167] Early clinical trials to evaluate safety and efficacy of these agents are expected. 
Table 7: Preclinical development of novel strategies targeting heregulin-mediated pathways

\begin{tabular}{|c|c|c|}
\hline Class & Drugs & Proposed mechanism of action \\
\hline \multirow{2}{*}{$\begin{array}{l}\text { metalloproteinase } \\
\text { inhibitors }\end{array}$} & $\begin{array}{l}\text { INCB3619 } \\
\text { D1(A12) }\end{array}$ & $\begin{array}{l}\text { ADAM17 (TACE) inhibitor; } \\
\text { prevents shedding of } \mathrm{HRG} \text { and } \\
\text { consequent binding to target } \\
\text { receptors }\end{array}$ \\
\hline & $\begin{array}{l}\text { Batimastat } \\
(\text { BB-94) }\end{array}$ & $\begin{array}{l}\text { Broad spectrum metalloproteinase } \\
\text { inhibitor; prevents shedding of } \\
\text { HRG and consequent binding to } \\
\text { target receptors }\end{array}$ \\
\hline \multirow{3}{*}{$\begin{array}{l}\text { Heregulin } \\
\text { proteins }\end{array}$} & $\begin{array}{l}\text { HAR-TX beta } \\
2\end{array}$ & $\begin{array}{l}\text { heregulin-beta } 2 \text { fused to a binding- } \\
\text { defective form of Pseudomonas } \\
\text { exotoxin A; induce cell cytotoxicity } \\
\text { preferentially in HER4-positive } \\
\text { vells }\end{array}$ \\
\hline & DT(389)hrg & $\begin{array}{l}\text { a chimera of diphtheria toxin and } \\
\text { EGF-like domain of heregulin } \\
\text { beta1 induced cytotoxicity against } \\
\text { HER3 and/or HER4-expressing } \\
\text { cell lines }\end{array}$ \\
\hline & $\begin{array}{l}\text { Heregulin- } \\
\text { IL2 fusions } \\
\text { protein }\end{array}$ & $\begin{array}{l}\text { can redirect non-tumor specific } \\
\text { cytotoxic lymphocytes to the tumor } \\
\text { site and induce lysis of tumor cells } \\
\text { in a non-MHC-restricted manner }\end{array}$ \\
\hline $\begin{array}{l}\text { Chimeric antigen } \\
\text { receptor (CAR)-T cells }\end{array}$ & $\begin{array}{l}\text { Heregulin-zeta } \\
\text { T cell receptor }\end{array}$ & $\begin{array}{l}\text { Increases recognition and } \\
\text { elimination of target cells (HER3 } \\
\text { and HER4-positive cells) }\end{array}$ \\
\hline $\begin{array}{l}\text { Soluble } \\
\text { receptors }\end{array}$ & $\begin{array}{l}\text { sErbB4.497. } \\
\text { Fc }\end{array}$ & $\begin{array}{l}\text { A fusion protein constituted of the } \\
\text { ErbB4 ectodomain fused to the } \\
\text { human IgG Fc constant region; } \\
\text { traps heregulin and betacellulin } \\
\text { preventing receptor activation }\end{array}$ \\
\hline $\begin{array}{l}\text { HER3 antisense } \\
\text { oligonucleotide }\end{array}$ & EZN-3920 & downmodulate HER3 expression \\
\hline anti-HER4 antibody & clone P6-1 & $\begin{array}{l}\text { reduced MCF7 tumor growth; } \\
\text { reduces HER4 activation possibly } \\
\text { through impairing ligand binding }\end{array}$ \\
\hline
\end{tabular}

\section{Heregulin fusion proteins}

Chimeric HRG-toxin fusion proteins consisting of a HRG, or at least the EGF-like extracellular binding domain, attached to Pseudomonas exotoxin A or diphtheria toxin have shown cytotoxic activity against human breast tumor cell lines expressing HER3 and/or HER4.[168, 169] HER4 expression may be necessary for HRG-toxin fusion protein cytotoxicity.[170, 171] Yang et al. tested eight chimeric toxins composed of the extracellular EGF-like domains of four HRG isoforms combined with truncated Pseudomonas exotoxin (PE38KDEL) and found that the EGF-like domain of HRG13 and HRGbeta2 demonstrated the highest cytotoxic activity.[170]

Bivalent HRG ligands composed of two linked NRG or EGF moieties have been engineered to increase HER homodimer formation and prevent the formation of HER3/ HER2 heterodimers. In vitro, HRG-HRG fusion proteins inhibit migration and proliferation and induce apoptosis of cancer cells.[172] Other fusion proteins composed of HRG attached to IL-2 or CD3 have been developed to bring $\mathrm{T}$ cells into proximity of tumor cells expressing HERs. Lustgarten et al. showed that HRG-IL-2 fusions proteins can redirect non-tumor specific cytotoxic lymphocytes to the tumor site and induce lysis of tumor cells in a nonMHC-restricted manner.[173] The fusion protein of HRG attached to the CD3 zeta-chain causes $\mathrm{T}$ lymphocytes to recognize and attack breast cancer cells overexpressing HER3 and HER4.[174, 175]

A fusion protein (sErbB4.497.Fc) comprised of the HER4 ectodomain fused to the human IgG Fc constant region was created and is able to efficiently bind to betacellulin and HRG-beta1 with high affinity. When HRG was bound to the fusion protein receptor, EGFR phosphorylation and downstream signaling were inhibited. The fusion receptor also inhibited proliferation of breast cancer cell lines and had a modest effect on tumor growth in a mouse model.[176] 


\section{Silencing of HER3 expression}

A locked nucleic acid-based HER3 antisense oligonucleotide (EZN-3920) decreased HER3 mRNA expression and tumor growth in breast and lung cancer models.[177] Table 7 summarizes the proposed mechanism of action of these promising novel strategies targeting HRG-mediated pathways under preclinical development.

\section{CONCLUSIONS}

Activation of the HRG signaling network is relevant to various malignancies and is associated with worse clinical outcomes. The presence of multiple types of HRGs and receptors combined with complex downstream signaling makes the translation of preclinical discoveries into effective therapeutics challenging. Nevertheless, several molecules targeting HRG-related pathways are in clinical development and have shown favorable toxicity profiles and preliminary efficacy in several malignancies, alone and in combination with other therapies. Given the extensive crosstalk of HRG-dependent signaling with pivotal pathways regulating both carcinogenesis and treatment resistance, the future of HRG-based therapies may rely on combination with other targeted agents or sequencing treatments guided by emergence of resistance. There is also potential for combination with immunotherapy. The HRG fusion proteins involving IL-2 or CD3 create an interface between the HRG/ HER pathway and the immune system, building the foundation for combinations with checkpoint inhibitors and better understanding of the role of HRG signaling in the anti-tumor immune response. A promising strategy is to reverse resistance to anti-HER2 treatment through targeting HRG-dependent pathways in biomarker-selected individuals. Further validation of biomarkers reflecting tumor dependence on the HRG/HER pathway will assist with improved patient selection for treatments targeting this pathway. For example, the promising results of the anti-HER3 antibody seribantumab in subgroups of breast and ovarian cancers with high expression of heregulin highlight the critical importance of validated biomarkers. A promising strategy is to targeting HER3 to reverse resistance to anti-HER2 treatment in biomarker-selected individuals. Between the demonstrated involvement of the HRG/HER pathway in multiple cancer types, the proven efficacy of therapies targeting this pathway, and the extensive list of novel agents in development, it is expected that therapies targeting HRG, HER3, and HER4 will have a meaningful clinical impact on cancer treatment.

\section{Abbreviations}

ADAM17-ADAM metallopeptidase domain 17; AKT-protein kinase B; APIP-Apaf-1-interacting protein; BRAF-B-Raf and v-Raf murine sarcoma viral oncogene homolog B; CSC-cancer stem cell; CRC-colorectal cancer; EBP-1-ErbB3-binding protein 1; EOC-epithelial ovarian carcinoma; EHCCs-extra-hepatic cholangiocarcinomas; ERK-Extracellular Signal-regulated Kinase; GCgastric cancer; HER-human epithelial receptor; HCVhepatitis C virus; HNSCCs-head and neck squamous cell carcinoma; HRGs-heregulins; ICD-intracellular domain; IHCCs-intrahepatic cholangiocarcinomas; IL-2interleukin-2; JAK-janus kinase; JNK-c-Jun N-terminal kinases; MAPK-Mitogen-activated protein kinase; mCRC-metastatic colorectal cancer; MEK-MAPK kinase; MITF-microphtalmia-associated transcription factor; MTOR-mechanistic target of rapamycin; NDFneu differentiation factor; NEDD4-neural precursor cell expressed developmentally downregulated-4; NSCLC-non small cell lung cancer; NRG-neuregulin; PDA-pancreatic ductal adenocarcinoma; PI3K-phosphatidylinositol-3kinases; SNP-single nucleotide polymorphism; STATSignal Transducer and Activator of Transcription; TACE-tumor necrosing factor alpha converting enzyme; VEGF-Vascular endothelial growth factor; TCGA-The Cancer Genome Atlas; YAP-Yes-associated protein.

\section{ACKNOWLEDGEMENTS}

We would like to thank The Woman's Board of Northwestern Memorial Hospital. The authors declare no conflicts of interest regarding this publication.

\section{CONFLICTS OF INTEREST}

There is no conflict of interest.

\section{REFERENCES}

1. Breuleux M. Role of heregulin in human cancer. Cell Mol Life Sci. 2007; 64:2358-77.

2. Khurana A, Gonzalez-Guerrico A, Lupu R. Heregulin in breast cancer: old story, new paradigm. Curr Pharm Des. 2014; 20:4874-78.

3. Peles E, Bacus SS, Koski RA, Lu HS, Wen D, Ogden SG, Levy RB, Yarden Y. Isolation of the neu/HER-2 stimulatory ligand: a 44 kd glycoprotein that induces differentiation of mammary tumor cells. Cell. 1992; 69:205-16.

4. Holmes WE, Sliwkowski MX, Akita RW, Henzel WJ, Lee J, Park JW, Yansura D, Abadi N, Raab H, Lewis GD, Shepard HM, Kuang WJ, Wood W, et al. Identification of heregulin, a specific activator of p185erbB2. Science. 1992; 256:1205-10. 
5. Peles E, Ben-Levy R, Tzahar E, Liu N, Wen D, Yarden Y. Cell-type specific interaction of Neu differentiation factor (NDF/heregulin) with Neu/HER-2 suggests complex ligand-receptor relationships. EMBO J. 1993; 12:961-71.

6. Tzahar E, Levkowitz G, Karunagaran D, Yi L, Peles E, Lavi S, Chang D, Liu N, Yayon A, Wen D, Yarden Y. ErbB-3 and ErbB-4 function as the respective low and high affinity receptors of all Neu differentiation factor/heregulin isoforms. J Biol Chem. 1994; 269:25226-33.

7. Weinstein EJ, Leder P. The extracellular region of heregulin is sufficient to promote mammary gland proliferation and tumorigenesis but not apoptosis. Cancer Res. 2000; 60:3856-61.

8. Montero JC, Yuste L, Díaz-Rodríguez E, Esparís-Ogando A, Pandiella A. Differential shedding of transmembrane neuregulin isoforms by the tumor necrosis factor-alphaconverting enzyme. Mol Cell Neurosci. 2000; 16:631-48.

9. Bouyain S, Longo PA, Li S, Ferguson KM, Leahy DJ. The extracellular region of ErbB4 adopts a tethered conformation in the absence of ligand. Proc Natl Acad Sci USA. 2005; 102:15024-29.

10. Chen X, Levkowitz G, Tzahar E, Karunagaran D, Lavi S, Ben-Baruch N, Leitner O, Ratzkin BJ, Bacus SS, Yarden Y. An immunological approach reveals biological differences between the two NDF/heregulin receptors, ErbB-3 and ErbB-4. J Biol Chem. 1996; 271:7620-29.

11. Alimandi M, Romano A, Curia MC, Muraro R, Fedi P, Aaronson SA, Di Fiore PP, Kraus MH. Cooperative signaling of ErbB3 and ErbB2 in neoplastic transformation and human mammary carcinomas. Oncogene. 1995; 10:1813-21.

12. Li Z, Mei Y, Liu X, Zhou M. Neuregulin-1 only induces trans-phosphorylation between ErbB receptor heterodimer partners. Cell Signal. 2007; 19:466-71.

13. Monsey J, Shen W, Schlesinger P, Bose R. Her4 and Her2/ neu tyrosine kinase domains dimerize and activate in a reconstituted in vitro system. J Biol Chem. 2010; 285:703544.

14. Collier TS, Diraviyam K, Monsey J, Shen W, Sept D, Bose R. Carboxyl group footprinting mass spectrometry and molecular dynamics identify key interactions in the HER2HER3 receptor tyrosine kinase interface. J Biol Chem. 2013; 288:25254-64.

15. Sweeney C, Carraway KL 3rd. Ligand discrimination by ErbB receptors: differential signaling through differential phosphorylation site usage. Oncogene. 2000; 19:5568-73.

16. Campbell MR, Amin D, Moasser MM. HER3 comes of age: new insights into its functions and role in signaling, tumor biology, and cancer therapy. Clin Cancer Res. 2010; 16:1373-83.

17. Zhang N, Chang Y, Rios A, An Z. HER3/ErbB3, an emerging cancer therapeutic target. Acta Biochim Biophys Sin (Shanghai). 2016; 48:39-48.

18. Telesco SE, Vadigepalli R, Radhakrishnan R. Molecular modeling of ErbB4/HER4 kinase in the context of the HER4 signaling network helps rationalize the effects of clinically identified HER4 somatic mutations on the cell phenotype. Biotechnol J. 2013; 8:1452-64.

19. Okazaki S, Nakatani F, Masuko K, Tsuchihashi K, Ueda S, Masuko T, Saya H, Nagano O. Development of an ErbB4 monoclonal antibody that blocks neuregulin-1-induced ErbB4 activation in cancer cells. Biochem Biophys Res Commun. 2016; 470:239-44.

20. Wali VB, Haskins JW, Gilmore-Hebert M, Platt JT, Liu Z, Stern DF. Convergent and divergent cellular responses by ErbB4 isoforms in mammary epithelial cells. Mol Cancer Res. 2014; 12:1140-55.

21. Paatero I, Jokilammi A, Heikkinen PT, Iljin K, Kallioniemi OP, Jones FE, Jaakkola PM, Elenius K. Interaction with ErbB4 promotes hypoxia-inducible factor- $1 \alpha$ signaling. J Biol Chem. 2012; 287:9659-71.

22. Haskins JW, Nguyen DX, Stern DF. Neuregulin 1-activated ERBB4 interacts with YAP to induce Hippo pathway target genes and promote cell migration. Sci Signal. 2014; 7:ra116.

23. Sartor CI, Zhou H, Kozlowska E, Guttridge K, Kawata E, Caskey L, Harrelson J, Hynes N, Ethier S, Calvo B, Earp HS 3rd. Her4 mediates ligand-dependent antiproliferative and differentiation responses in human breast cancer cells. Mol Cell Biol. 2001; 21:4265-75.

24. Muraoka-Cook RS, Caskey LS, Sandahl MA, Hunter DM, Husted C, Strunk KE, Sartor CI, Rearick WA Jr, McCall W, Sgagias MK, Cowan KH, Earp HS 3rd. Heregulindependent delay in mitotic progression requires HER4 and BRCA1. Mol Cell Biol. 2006; 26:6412-24.

25. Lee H, Akita RW, Sliwkowski MX, Maihle NJ. A naturally occurring secreted human ErbB3 receptor isoform inhibits heregulin-stimulated activation of ErbB2, ErbB3, and ErbB4. Cancer Res. 2001; 61:4467-73.

26. Das S, Czarnek M, Bzowska M, Mężyk-Kopeć R, Stalińska K, Wyroba B, Sroka J, Jucha J, Deneka D, Stokłosa P, Ogonek J, Swartz MA, Madeja Z, Bereta J. ADAM17 silencing in mouse colon carcinoma cells: the effect on tumoricidal cytokines and angiogenesis. PLoS One. 2012; 7:e50791.

27. Huang Z, Choi BK, Mujoo K, Fan X, Fa M, Mukherjee S, Owiti N, Zhang N, An Z. The E3 ubiquitin ligase NEDD4 negatively regulates HER3/ErbB3 level and signaling. Oncogene. 2015; 34:1105-15.

28. Williams CS, Bernard JK, Demory Beckler M, Almohazey D, Washington MK, Smith JJ, Frey MR. ERBB4 is overexpressed in human colon cancer and enhances cellular transformation. Carcinogenesis. 2015; 36:710-18.

29. Frey MR, Hilliard VC, Mullane MT, Polk DB. ErbB4 promotes cyclooxygenase-2 expression and cell survival in colon epithelial cells. Lab Invest. 2010; 90:1415-24.

30. Jaiswal BS, Kljavin NM, Stawiski EW, Chan E, Parikh C, Durinck S, Chaudhuri S, Pujara K, Guillory J, Edgar KA, 
Janakiraman V, Scholz RP, Bowman KK, et al. Oncogenic ERBB3 mutations in human cancers. Cancer Cell. 2013; 23:603-17.

31. Soung YH, Lee JW, Kim SY, Wang YP, Jo KH, Moon SW, Park WS, Nam SW, Lee JY, Yoo NJ, Lee SH. Somatic mutations of the ERBB4 kinase domain in human cancers. Int J Cancer. 2006; 118:1426-29.

32. Mitsui K, Yonezawa M, Tatsuguchi A, Shinji S, Gudis K, Tanaka S, Fujimori S, Sakamoto C. Localization of phosphorylated ErbB1-4 and heregulin in colorectal cancer. BMC Cancer. 2014; 14:863.

33. Beji A, Horst D, Engel J, Kirchner T, Ullrich A. Toward the prognostic significance and therapeutic potential of HER3 receptor tyrosine kinase in human colon cancer. Clin Cancer Res. 2012; 18:956-68.

34. Yonesaka K, Takegawa N, Satoh T, Ueda H, Yoshida T, Takeda M, Shimizu T, Chiba Y, Okamoto I, Nishio K, Tamura T, Nakagawa K. Combined Analysis of Plasma Amphiregulin and Heregulin Predicts Response to Cetuximab in Metastatic Colorectal Cancer. PLoS One. 2015; 10:e143132.

35. Prasetyanti PR, Capone E, Barcaroli D, D'Agostino D, Volpe S, Benfante A, van Hooff S, Iacobelli V, Rossi C, Iacobelli S, Medema JP, De Laurenzi V, Sala G. ErbB3 activation by NRG-1 $\beta$ sustains growth and promotes vemurafenib resistance in BRAF-V600E colon cancer stem cells (CSCs). Oncotarget. 2015; 6:16902-11. https://doi. org/10.18632/oncotarget.4642

36. Timotheadou E, Skarlos DV, Samantas E, Papadopoulos S, Murray S, Skrickova J, Christodoulou C, Papakostantinou C, Pectasides D, Papakostas P, Kaplanova J, Vrettou E, Karina M, et al. Evaluation of the prognostic role of a panel of biomarkers in stage IB-IIIA non-small cell lung cancer patients. Anticancer Res. 2007; 27:4481-89.

37. Younes M, Wu Z, Dupouy S, Lupo AM, Mourra N, Takahashi T, Fléjou JF, Trédaniel J, Régnard JF, Damotte D, Alifano M, Forgez P. Neurotensin (NTS) and its receptor (NTSR1) causes EGFR, HER2 and HER3 over-expression and their autocrine/paracrine activation in lung tumors, confirming responsiveness to erlotinib. Oncotarget. 2014; 5:8252-69. https://doi.org/10.18632/oncotarget.1633

38. Pan B, Wang R, Huang Y, Garfield D, Zhang J, Chen H. HGF and NRG1 protein expression are not poor prognostic markers in surgically resected lung adenocarcinoma. Onco Targets Ther. 2015; 8:1185-91.

39. Jung Y, Yong S, Kim P, Lee HY, Jung Y, Keum J, Lee S, Kim J, Kim J. VAMP2-NRG1 Fusion Gene is a Novel Oncogenic Driver of Non-Small-Cell Lung Adenocarcinoma. J Thorac Oncol. 2015; 10:1107-11.

40. Fernandez-Cuesta L, Plenker D, Osada H, Sun R, Menon R, Leenders F, Ortiz-Cuaran S, Peifer M, Bos M, Daßler J, Malchers F, Schöttle J, Vogel W, et al. CD74-NRG1 fusions in lung adenocarcinoma. Cancer Discov. 2014; $4: 415-22$.
41. Isozaki H, Ichihara E, Takigawa N, Ohashi K, Ochi N, Yasugi M, Ninomiya T, Yamane H, Hotta K, Sakai K, Matsumoto K, Hosokawa S, Bessho A, et al. Non-Small Cell Lung Cancer Cells Acquire Resistance to the ALK Inhibitor Alectinib by Activating Alternative Receptor Tyrosine Kinases. Cancer Res. 2016; 76:1506-16.

42. Dong X, Fernandez-Salas E, Li E, Wang S. Elucidation of Resistance Mechanisms to Second-Generation ALK Inhibitors Alectinib and Ceritinib in Non-Small Cell Lung Cancer Cells. Neoplasia. 2016; 18:162-71.

43. Tanizaki J, Okamoto I, Okabe T, Sakai K, Tanaka K, Hayashi H, Kaneda H, Takezawa K, Kuwata K, Yamaguchi H, Hatashita E, Nishio K, Nakagawa K. Activation of HER family signaling as a mechanism of acquired resistance to ALK inhibitors in EML4-ALK-positive non-small cell lung cancer. Clin Cancer Res. 2012; 18:6219-26.

44. Hegde GV, de la Cruz CC, Chiu C, Alag N, Schaefer G, Crocker L, Ross S, Goldenberg D, Merchant M, Tien J, Shao L, Roth L, Tsai SP, et al. Blocking NRG1 and other ligand-mediated Her4 signaling enhances the magnitude and duration of the chemotherapeutic response of non-small cell lung cancer. Sci Transl Med. 2013; 5:171ra18.

45. Qian G, Jiang N, Wang D, Newman S, Kim S, Chen Z, Garcia G, MacBeath G, Shin DM, Khuri FR, Chen ZG, Saba NF. Heregulin and HER3 are prognostic biomarkers in oropharyngeal squamous cell carcinoma. Cancer. 2015; 121:3600-11.

46. O-Charoenrat P, Rhys-Evans P, Eccles S. Expression and regulation of c-ERBB ligands in human head and neck squamous carcinoma cells. Int J Cancer. 2000; 88:759-65.

47. Takikita M, Xie R, Chung JY, Cho H, Ylaya K, Hong SM, Moskaluk CA, Hewitt SM. Membranous expression of Her3 is associated with a decreased survival in head and neck squamous cell carcinoma. J Transl Med. 2011; 9:126.

48. Huang Y, Benaich N, Tape C, Kwok HF, Murphy G. Targeting the sheddase activity of ADAM17 by an antiADAM17 antibody D1(A12) inhibits head and neck squamous cell carcinoma cell proliferation and motility via blockage of bradykinin induced HERs transactivation. Int J Biol Sci. 2014; 10:702-14.

49. Zhang K, Jones L, Lim S, Maher CA, Adkins D, Lewis J, Kimple RJ, Fertig EJ, Chung CH, Van Tine BA, Ellis MJ, Herrlich A, Michel LS. Loss of Trop2 causes ErbB3 activation through a neuregulin-1-dependent mechanism in the mesenchymal subtype of HNSCC. Oncotarget. 2014; 5:9281-94. https://doi.org/10.18632/oncotarget.2423

50. Shames DS, Carbon J, Walter K, Jubb AM, Kozlowski C, Januario T, Do A, Fu L, Xiao Y, Raja R, Jiang B, Malekafzali A, Stern H, et al. High heregulin expression is associated with activated HER3 and may define an actionable biomarker in patients with squamous cell carcinomas of the head and neck. PLoS One. 2013; 8:e56765.

51. Yamano Y, Uzawa K, Saito K, Nakashima D, Kasamatsu A, Koike H, Kouzu Y, Shinozuka K, Nakatani K, Negoro K, 
Fujita S, Tanzawa H. Identification of cisplatin-resistance related genes in head and neck squamous cell carcinoma. Int J Cancer. 2010; 126:437-49.

52. Oliveras-Ferraros C, Vazquez-Martin A, Queralt B, Adrados M, Ortiz R, Cufí S, Hernández-Yagüe X, Guardeño R, Báez L, Martin-Castillo B, Pérez-Martínez MC, Lopez-Bonet E, De Llorens R, et al. Interferon/ STAT1 and neuregulin signaling pathways are exploratory biomarkers of cetuximab (Erbitux $\left.{ }^{\circledR}\right)$ efficacy in KRAS wild-type squamous carcinomas: a pathway-based analysis of whole human-genome microarray data from cetuximabadapted tumor cell-line models. Int J Oncol. 2011; 39:145579.

53. Wilson TR, Lee DY, Berry L, Shames DS, Settleman J. Neuregulin-1-mediated autocrine signaling underlies sensitivity to HER2 kinase inhibitors in a subset of human cancers. Cancer Cell. 2011; 20:158-72.

54. Hayes NV, Blackburn E, Smart LV, Boyle MM, Russell GA, Frost TM, Morgan BJ, Baines AJ, Gullick WJ. Identification and characterization of novel spliced variants of neuregulin 4 in prostate cancer. Clin Cancer Res. 2007; 13:3147-55.

55. Soler M, Mancini F, Meca-Cortés O, Sánchez-Cid L, Rubio $\mathrm{N}$, López-Fernández S, Lozano JJ, Blanco J, Fernández PL, Thomson TM. HER3 is required for the maintenance of neuregulin-dependent and -independent attributes of malignant progression in prostate cancer cells. Int J Cancer. 2009; 125:2565-75.

56. Grimsley SJ, Shini S, Underwood MA, Edwards J. Heregulin expression and prognosis in prostate adenocarcinoma. Urol Int. 2011; 87:363-68.

57. Zhang Y, Linn D, Liu Z, Melamed J, Tavora F, Young CY, Burger AM, Hamburger AW. EBP1, an ErbB3-binding protein, is decreased in prostate cancer and implicated in hormone resistance. Mol Cancer Ther. 2008; 7:3176-86.

58. Zhou H, Mazan-Mamczarz K, Martindale JL, Barker A, Liu Z, Gorospe M, Leedman PJ, Gartenhaus RB, Hamburger AW, Zhang Y. Post-transcriptional regulation of androgen receptor mRNA by an ErbB3 binding protein 1 in prostate cancer. Nucleic Acids Res. 2010; 38:3619-31.

59. Lyne JC, Melhem MF, Finley GG, Wen D, Liu N, Deng $\mathrm{DH}$, Salup R. Tissue expression of neu differentiation factor/heregulin and its receptor complex in prostate cancer and its biologic effects on prostate cancer cells in vitro. Cancer J Sci Am. 1997; 3:21-30.

60. Gregory CW, Whang YE, McCall W, Fei X, Liu Y, Ponguta LA, French FS, Wilson EM, Earp HS 3rd. Heregulininduced activation of HER2 and HER3 increases androgen receptor transactivation and CWR-R1 human recurrent prostate cancer cell growth. Clin Cancer Res. 2005; 11:1704-12.

61. Tanner B, Hasenclever D, Stern K, Schormann W, Bezler M, Hermes M, Brulport M, Bauer A, Schiffer IB, Gebhard S, Schmidt M, Steiner E, Sehouli J, et al. ErbB-3 predicts survival in ovarian cancer. J Clin Oncol. 2006; 24:4317-23.
62. Gilmour LM, Macleod KG, McCaig A, Gullick WJ, Smyth JF, Langdon SP. Expression of erbB-4/HER-4 growth factor receptor isoforms in ovarian cancer. Cancer Res. 2001; 61:2169-76.

63. Gilmour LM, Macleod KG, McCaig A, Sewell JM, Gullick WJ, Smyth JF, Langdon SP. Neuregulin expression, function, and signaling in human ovarian cancer cells. Clin Cancer Res. 2002; 8:3933-42.

64. Bezler M, Hengstler JG, Ullrich A. Inhibition of doxorubicin-induced HER3-PI3K-AKT signalling enhances apoptosis of ovarian cancer cells. Mol Oncol. 2012; 6:51629.

65. McEvoy LM, O'Toole SA, Spillane CD, Martin CM, Gallagher MF, Stordal B, Blackshields G, Sheils O, O'Leary JJ. Identifying novel hypoxia-associated markers of chemoresistance in ovarian cancer. BMC Cancer. 2015; 15:547.

66. Jia Y, Zhang Y, Qiao C, Liu G, Zhao Q, Zhou T, Chen G, Li Y, Feng J, Li Y, Zhang Q, Peng H. IGF-1R and ErbB3/HER3 contribute to enhanced proliferation and carcinogenesis in trastuzumab-resistant ovarian cancer model. Biochem Biophys Res Commun. 2013; 436:740-45.

67. Makhija S, Amler LC, Glenn D, Ueland FR, Gold MA, Dizon DS, Paton V, Lin CY, Januario T, Ng K, Strauss A, Kelsey S, Sliwkowski MX, Matulonis U. Clinical activity of gemcitabine plus pertuzumab in platinum-resistant ovarian cancer, fallopian tube cancer, or primary peritoneal cancer. J Clin Oncol. 2010; 28:1215-23.

68. Kristjansdottir K, Dizon D. HER-dimerization inhibitors: evaluating pertuzumab in women's cancers. Expert Opin Biol Ther. 2010; 10:243-50.

69. Bièche I, Onody P, Tozlu S, Driouch K, Vidaud M, Lidereau R. Prognostic value of ERBB family mRNA expression in breast carcinomas. Int J Cancer. 2003; 106:758-65.

70. Esteva FJ, Hortobagyi GN, Sahin AA, Smith TL, Chin DM, Liang SY, Pusztai L, Buzdar AU, Bacus SS. Expression of erbB/HER receptors, heregulin and $\mathrm{P} 38$ in primary breast cancer using quantitative immunohistochemistry. Pathol Oncol Res. 2001; 7:171-77.

71. Bae SY, La Choi Y, Kim S, Kim M, Kim J, Jung SP, Choi MY, Lee SK, Kil WH, Lee JE, Nam SJ. HER3 status by immunohistochemistry is correlated with poor prognosis in hormone receptor-negative breast cancer patients. Breast Cancer Res Treat. 2013; 139:741-50.

72. Lipton A, Goodman L, Leitzel K, Cook J, Sperinde J, Haddad M, Köstler WJ, Huang W, Weidler JM, Ali S, Newton A, Fuchs EM, Paquet A, et al. HER3, p95HER2, and HER2 protein expression levels define multiple subtypes of HER2-positive metastatic breast cancer. Breast Cancer Res Treat. 2013; 141:43-53.

73. Lee-Hoeflich ST, Crocker L, Yao E, Pham T, Munroe X, Hoeflich KP, Sliwkowski MX, Stern HM. A central role for HER3 in HER2-amplified breast cancer: implications for targeted therapy. Cancer Res. 2008; 68:5878-87. 
74. Vaught DB, Stanford JC, Young C, Hicks DJ, Wheeler F, Rinehart C, Sánchez V, Koland J, Muller WJ, Arteaga CL, Cook RS. HER3 is required for HER2-induced preneoplastic changes to the breast epithelium and tumor formation. Cancer Res. 2012; 72:2672-82.

75. Desmedt C, Zoppoli G, Gundem G, Pruneri G, Larsimont D, Fornili M, Fumagalli D, Brown D, Rothé F, Vincent D, Kheddoumi N, Rouas G, Majjaj S, et al. Genomic Characterization of Primary Invasive Lobular Breast Cancer. J Clin Oncol. 2016; 34:1872-81.

76. Sundvall M, Iljin K, Kilpinen S, Sara H, Kallioniemi OP, Elenius K. Role of ErbB4 in breast cancer. J Mammary Gland Biol Neoplasia. 2008; 13:259-68.

77. Thor AD, Edgerton SM, Jones FE. Subcellular localization of the HER4 intracellular domain, 4ICD, identifies distinct prognostic outcomes for breast cancer patients. Am J Pathol. 2009; 175:1802-09.

78. Perou CM, Sørlie T, Eisen MB, van de Rijn M, Jeffrey SS, Rees CA, Pollack JR, Ross DT, Johnsen H, Akslen LA, Fluge O, Pergamenschikov A, Williams C, et al. Molecular portraits of human breast tumours. Nature. 2000; 406:74752.

79. Machleidt A, Buchholz S, Diermeier-Daucher S, Zeman F, Ortmann O, Brockhoff G. The prognostic value of Her4 receptor isoform expression in triple-negative and Her2 positive breast cancer patients. BMC Cancer. 2013; 13:437.

80. Mohd Nafi SN, Generali D, Kramer-Marek G, Gijsen M, Strina C, Cappelletti M, Andreis D, Haider S, Li JL, Bridges E, Capala J, Ioannis R, Harris AL, Kong A. Nuclear HER4 mediates acquired resistance to trastuzumab and is associated with poor outcome in HER2 positive breast cancer. Oncotarget. 2014; 5:5934-49. https://doi. org/10.18632/oncotarget.1904

81. Yang Y, Spitzer E, Meyer D, Sachs M, Niemann C, Hartmann G, Weidner KM, Birchmeier C, Birchmeier W. Sequential requirement of hepatocyte growth factor and neuregulin in the morphogenesis and differentiation of the mammary gland. J Cell Biol. 1995; 131:215-26.

82. Kogata N, Zvelebil M, Howard BA. Neuregulin 3 and erbb signalling networks in embryonic mammary gland development. J Mammary Gland Biol Neoplasia. 2013; 18:149-54.

83. Stern DF. ERBB3/HER3 and ERBB2/HER2 duet in mammary development and breast cancer. J Mammary Gland Biol Neoplasia. 2008; 13:215-23.

84. Révillion F, Lhotellier V, Hornez L, Bonneterre J, Peyrat JP. ErbB/HER ligands in human breast cancer, and relationships with their receptors, the bio-pathological features and prognosis. Ann Oncol. 2008; 19:73-80.

85. Prentice LM, Shadeo A, Lestou VS, Miller MA, deLeeuw RJ, Makretsov N, Turbin D, Brown LA, Macpherson N, Yorida E, Cheang MC, Bentley J, Chia S, et al. NRG1 gene rearrangements in clinical breast cancer: identification of an adjacent novel amplicon associated with poor prognosis.
Oncogene. 2005; 24:7281-89.

86. Tang CK, Perez C, Grunt T, Waibel C, Cho C, Lupu R. Involvement of heregulin-beta2 in the acquisition of the hormone-independent phenotype of breast cancer cells. Cancer Res. 1996; 56:3350-58.

87. Atlas E, Cardillo M, Mehmi I, Zahedkargaran H, Tang C, Lupu R. Heregulin is sufficient for the promotion of tumorigenicity and metastasis of breast cancer cells in vivo. Mol Cancer Res. 2003; 1:165-75.

88. Yao J, Xiong S, Klos K, Nguyen N, Grijalva R, Li P, Yu D. Multiple signaling pathways involved in activation of matrix metalloproteinase-9 (MMP-9) by heregulin-beta1 in human breast cancer cells. Oncogene. 2001; 20:8066-74.

89. Bagheri-Yarmand R, Vadlamudi RK, Wang RA, Mendelsohn J, Kumar R. Vascular endothelial growth factor up-regulation via p21-activated kinase-1 signaling regulates heregulin-beta1-mediated angiogenesis. J Biol Chem. 2000; 275:39451-57.

90. Jeong H, Kim J, Lee Y, Seo JH, Hong SR, Kim A. Neuregulin-1 induces cancer stem cell characteristics in breast cancer cell lines. Oncol Rep. 2014; 32:1218-24.

91. Menendez JA, Rubio MA, Campisi J, Lupu R. Heregulin, a new regulator of telomere length in human cells. Oncotarget. 2015; 6:39422-36. https://doi.org/10.18632/ oncotarget.4964

92. Pérez-Tenorio G, Stål O, and Southeast Sweden Breast Cancer Group. Activation of AKT/PKB in breast cancer predicts a worse outcome among endocrine treated patients. Br J Cancer. 2002; 86:540-45.

93. Marshall C, Blackburn E, Clark M, Humphreys S, Gullick WJ. Neuregulins 1-4 are expressed in the cytoplasm or nuclei of ductal carcinoma (in situ) of the human breast. Breast Cancer Res Treat. 2006; 96:163-68.

94. Raj EH, Skinner A, Mahji U, Nirmala KN, Ravichandran K, Shanta V, Hurst HC, Gullick WJ, Rajkumar T. Neuregulin 1-alpha expression in locally advanced breast cancer. Breast. 2001; 10:41-45.

95. Baselga J, Cortés J, Im SA, Clark E, Ross G, Kiermaier A, Swain SM. Biomarker analyses in CLEOPATRA: a phase III, placebo-controlled study of pertuzumab in human epidermal growth factor receptor 2-positive, first-line metastatic breast cancer. J Clin Oncol. 2014; 32:3753-61.

96. Ebbing EA, Medema JP, Damhofer H, Meijer SL, Krishnadath KK, van Berge Henegouwen MI, Bijlsma MF, van Laarhoven HW. ADAM10-mediated release of heregulin confers resistance to trastuzumab by activating HER3. Oncotarget. 2016; 7:10243-54. https://doi. org/10.18632/oncotarget.7200

97. Xia W, Petricoin EF 3rd, Zhao S, Liu L, Osada T, Cheng Q, Wulfkuhle JD, Gwin WR, Yang X, Gallagher RI, Bacus S, Lyerly HK, Spector NL. An heregulin-EGFR-HER3 autocrine signaling axis can mediate acquired lapatinib resistance in HER2+ breast cancer models. Breast Cancer Res. 2013; 15:R85. 
98. de Alava E, Ocaña A, Abad M, Montero JC, EsparísOgando A, Rodríguez CA, Otero AP, Hernández T, Cruz JJ, Pandiella A. Neuregulin expression modulates clinical response to trastuzumab in patients with metastatic breast cancer. J Clin Oncol. 2007; 25:2656-63.

99. Phillips GD, Fields CT, Li G, Dowbenko D, Schaefer G, Miller K, Andre F, Burris HA 3rd, Albain KS, Harbeck N, Dieras V, Crivellari D, Fang L, et al. Dual targeting of HER2-positive cancer with trastuzumab emtansine and pertuzumab: critical role for neuregulin blockade in antitumor response to combination therapy. Clin Cancer Res. 2014; 20:456-68.

100. Li C, Brand TM, Iida M, Huang S, Armstrong EA, van der Kogel A, Wheeler DL. Human epidermal growth factor receptor 3 (HER3) blockade with U3-1287/AMG888 enhances the efficacy of radiation therapy in lung and head and neck carcinoma. Discov Med. 2013; 16:79-92.

101. Kawakami H, Okamoto I, Yonesaka K, Okamoto K, Shibata K, Shinkai Y, Sakamoto H, Kitano M, Tamura T, Nishio $\mathrm{K}$, Nakagawa K. The anti-HER3 antibody patritumab abrogates cetuximab resistance mediated by heregulin in colorectal cancer cells. Oncotarget. 2014; 5:11847-56. https://doi.org/10.18632/oncotarget.2663

102. Iida M, Brand TM, Starr MM, Huppert EJ, Luthar N, Bahrar H, Coan JP, Pearson HE, Salgia R, Wheeler DL. Overcoming acquired resistance to cetuximab by dual targeting HER family receptors with antibody-based therapy. Mol Cancer. 2014; 13:242.

103. Cheng H, Terai M, Kageyama K, Ozaki S, McCue PA, Sato T, Aplin AE. Paracrine Effect of NRG1 and HGF Drives Resistance to MEK Inhibitors in Metastatic Uveal Melanoma. Cancer Res. 2015; 75:2737-48.

104. LoRusso P, Jänne PA, Oliveira M, Rizvi N, Malburg L, Keedy V, Yee L, Copigneaux C, Hettmann T, Wu CY, Ang A, Halim AB, Beckman RA, et al. Phase I study of U3-1287, a fully human anti-HER3 monoclonal antibody, in patients with advanced solid tumors. Clin Cancer Res. 2013; 19:3078-87.

105. Nishio M, Horiike A, Murakami H, Yamamoto N, Kaneda H, Nakagawa K, Horinouchi H, Nagashima M, Sekiguchi M, Tamura T. Phase I study of the HER3-targeted antibody patritumab (U3-1287) combined with erlotinib in Japanese patients with non-small cell lung cancer. Lung Cancer. 2015; 88:275-81.

106. Von Pawel J, Jennifer T, Dediu M, Schumann C, Xiaoping J, Moritz B, Mendell-Harary J, Feng W, Copigneaux C, Beckman RA. Phase 2 HERALD study of patritumab (P) with erlotinib (E) in advanced NSCLC subjects (SBJs). J Clin Oncol. 2014:32.

107. Mendell J, Freeman DJ, Feng W, Hettmann T, Schneider M, Blum S, Ruhe J, Bange J, Nakamaru K, Chen S, Tsuchihashi Z, von Pawel J, Copigneaux C, Beckman RA. Clinical Translation and Validation of a Predictive Biomarker for Patritumab, an Anti-human Epidermal Growth Factor Receptor 3 (HER3) Monoclonal Antibody, in Patients With Advanced Non-small Cell Lung Cancer. EBioMedicine. 2015; 2:264-71.

108. Harrington KJ, Forster MD, Dillon M, Grove L, Adeleke S, Chen S, Diamond JS, Hannus H, Cooper K, Greenberg J. Patritumab (P) or placebo (PBO) plus cetuximab (C) and platinum-based therapy in squamous cell carcinoma of the head and neck (SCCHN): a phase 2 study. J Clin Oncol. 2016; 34: abstr TPS6104.

109. Schoeberl B, Faber AC, Li D, Liang MC, Crosby K, Onsum M, Burenkova O, Pace E, Walton Z, Nie L, Fulgham A, Song Y, Nielsen UB, et al. An ErbB3 antibody, MM-121, is active in cancers with ligand-dependent activation. Cancer Res. 2010; 70:2485-94.

110. Jiang N, Wang D, Hu Z, Shin HJ, Qian G, Rahman MA, Zhang H, Amin AR, Nannapaneni S, Wang X, Chen Z, Garcia G, MacBeath G, et al. Combination of antiHER3 antibody MM-121/SAR256212 and cetuximab inhibits tumor growth in preclinical models of head and neck squamous cell carcinoma. Mol Cancer Ther. 2014; 13:1826-36.

111. Sheng Q, Liu X, Fleming E, Yuan K, Piao H, Chen J, Moustafa Z, Thomas RK, Greulich H, Schinzel A, Zaghlul S, Batt D, Ettenberg S, et al. An activated ErbB3/NRG1 autocrine loop supports in vivo proliferation in ovarian cancer cells. Cancer Cell. 2010; 17:298-310.

112. Wang D, Qian G, Zhang H, Magliocca KR, Nannapaneni S, Amin AR, Rossi M, Patel M, El-Deiry M, Wadsworth JT, Chen Z, Khuri FR, Shin DM, et al. HER3 targeting sensitizes HNSCC to cetuximab by reducing HER3 activity and HER2/HER3 dimerization - evidence from cell line and patient derived xenograft models. Clin Cancer Res. 2017; 23:677-86.

113. Wang S, Huang J, Lyu H, Cai B, Yang X, Li F, Tan J, Edgerton SM, Thor AD, Lee CK, Liu B. Therapeutic targeting of erbB3 with MM-121/SAR256212 enhances antitumor activity of paclitaxel against erbB2overexpressing breast cancer. Breast Cancer Res. 2013; 15:R101.

114. Curley MD, Sabnis GJ, Wille L, Adiwijaya BS, Garcia G, Moyo V, Kazi AA, Brodie A, MacBeath G. Seribantumab, an Anti-ERBB3 Antibody, Delays the Onset of Resistance and Restores Sensitivity to Letrozole in an Estrogen Receptor-Positive Breast Cancer Model. Mol Cancer Ther. 2015; 14:2642-52.

115. Huang J, Wang S, Lyu H, Cai B, Yang X, Wang J, Liu B. The anti-erbB3 antibody MM-121/SAR256212 in combination with trastuzumab exerts potent antitumor activity against trastuzumab-resistant breast cancer cells. Mol Cancer. 2013; 12:134.

116. Arnedos M, Denlinger CS, Harb WA, Rixe O, Morris JC, Dy GK, Adjei AA, Pearlberg J, Follows S, Czibere AG, Jean-Charles Soria. A phase I study of MM-121 in combination with multiple anticancer therapies in patients with advanced solid tumors. J Clin Oncol. 2013; 31: abstr 2609. 
117. Cleary JM, McRee AJ, O’Neil BH, Sharma S, Pearlberg J, Manoli S, Kubasek WL, Korn MW. A phase 1 study of MM-121 (a fully human monoclonal antibody targeting the epidermal growth factor receptor family member ErbB3) in combination with cetuximab and irinotecan in patients with advanced cancers. J Clin Oncol. 2014; 32: abstr 3076.

118. Sequist LV, Modiano M, Rixe O, Natarajan C, Onsum M, Kubasek W, Andreas K, Nering R, Moyo V, Harb WA. Abstract C27: Targeting ErbB3 and EGFR in lung cancer patients: A phase I trial of MM-121 in combination with erlotinib in patients with non-small cell lung cancer (NSCLC). Mol Cancer Ther. 2011 (Suppl 1); 10:C27-27.

119. Finn G, Zhang H, Blois A, Mathews S, Kudla A, Baum J, Cielewicz M, Czibere A. A randomized trial of exemestane +/- seribantumab (MM-121) in postmenopausal women with locally advanced or metastatic ER/PR+ HER2- breast cancer: Final analysis and extended subgroup analysis. Clin Cancer Res. 2015; 23: abst A14.

120. Holmes FA, McIntyre KJ, Krop IE, Osborne CR, Smith JW II, Modiano MR, Gupta M, Downey LB, Nanda R, Saleh MN, Young JR, Horgan KE, Kubasek W, et al. Abstract P3-11-03: A randomized, phase 2 trial of preoperative MM121 with paclitaxel in triple negative (TN) and hormone receptor (HR) positive, HER2-negative breast cancer. Cancer Res. 2015; 75: abstr P3-11-3

121. Liu J, Ray-Coquard IL, Selle F, Poveda A, Cibula D, Hirte HW, Raspagliesi F, Gladieff L, Harter P, Schiavetto I, Tabah-Fisch IM, MacBeath G, Czibere AG, et al. A phase II randomized open-label study of MM-121, a fully human monoclonal antibody targeting ErbB3, in combination with weekly paclitaxel versus weekly paclitaxel in patients with platinum-resistant/refractory ovarian cancers. J Clin Oncol. 2014; 32: abstr 5519.

122. Sequist LV, Lopez-Chavez A, Doebele RC, Gray JE, Harb WA, Modiano MR, Jackman DM, Baggstrom MQ, Atmaca A, Felip E, Provencio M, Cobo M, Kripas CJ, et al. A randomized phase 2 trial of MM-121, a fully human monoclonal antibody targeting ErbB3, in combination with erlotinib in EGFR wild-type NSCLC patients. J Clin Oncol. 2014; 32: Abstr 8051.

123. Garner AP, Bialucha CU, Sprague ER, Garrett JT, Sheng Q, Li S, Sineshchekova O, Saxena P, Sutton CR, Chen D, Chen Y, Wang H, Liang J, et al. An antibody that locks HER3 in the inactive conformation inhibits tumor growth driven by HER2 or neuregulin. Cancer Res. 2013; 73:602435.

124. Garrett JT, Sutton CR, Kurupi R, Bialucha CU, Ettenberg SA, Collins SD, Sheng Q, Wallweber J, Defazio-Eli L, Arteaga CL. Combination of antibody that inhibits ligandindependent HER3 dimerization and a p110 $\alpha$ inhibitor potently blocks PI3K signaling and growth of HER2+ breast cancers. Cancer Res. 2013; 73:6013-23.

125. Reynolds KL, Juric D, Baselga J, Alsina M, Tabernero J, Bedard PL, Graham DM, Gonzalez-Angulo AM, GarridoLaguna I, Sharma S, Lin CC, Cohen EEW, Lee SH, et al.
A phase 1 study of LJM716 in patients with esophageal squamous cell carcinoma, head and neck cancer, or HER2overexpressing metastatic breast or gastric cancer. J Clin Oncol. 2014; 32: abstr 2517.

126. Esaki T, Oda H, Kajitani T, Kobayashi T, Tomomatsu J, Kakizume T, Watanabe T, Takeuchi H, Fukino K, Takahashi S. Abstract C120: phase I study of the safety and tolerability of LJM716 in Japanese patients with advanced solid tumors. Mol Cancer Ther. 2015; 14:C120-120.

127. Im SA, Juric D, Baselga J, Kong A, Martin P, Lin CC, Dees EC, Schellens JH, Braud FG, Delgado L, Zucchetto M, Tian $\mathrm{X}$, Fernandez R, et al. A phase 1 dose-escalation study of anti-HER3 monoclonal antibody LJM716 in combination with trastuzumab in patients with HER2-overexpressing metastatic breast or gastric cancer. J Clin Oncol. 2014; 32 : abstr 2519.

128. Shah PD, Chandarlapaty S, Ulaner G, Zamora S, Sterlin V, Iasonos A, Dickler MN, Moynahan ME, Hudis CA, Baselga J, Modi S. Abstract OT3-1-05: Phase I, open-label study evaluating the safety and tolerability of LJM716, BYL719 and trastuzumab in patients with metastatic HER2+ breast cancer. Cancer Res. 2015; 75: abstr OT3-1-05.

129. Zhang L, Castanaro C, Luan B, Yang K, Fan L, Fairhurst JL, Rafique A, Potocky TB, Shan J, Delfino FJ, Shi E, Huang T, Martin JH, et al. ERBB3/HER2 signaling promotes resistance to EGFR blockade in head and neck and colorectal cancer models. Mol Cancer Ther. 2014; 13:1345-55.

130. Papadopoulos KP, Adjei AA, Rasco DW, Liu L, Kao RJ, Brownstein CM, DiCioccio AT, Lowy I, Trail P, Wang D. Phase 1 study of REGN1400 (anti-ErbB3) combined with erlotinib or cetuximab in patients (pts) with advanced nonsmall cell lung cancer (NSCLC), colorectal cancer (CRC), or head and neck cancer (SCCHN). J Clin Oncol. 2014; 32: abstr 2516 .

131. Lee S, Greenlee EB, Amick JR, Ligon GF, Lillquist JS, Natoli EJ Jr, Hadari Y, Alvarado D, Schlessinger J. Inhibition of ErbB3 by a monoclonal antibody that locks the extracellular domain in an inactive configuration. Proc Natl Acad Sci USA. 2015; 112:13225-30.

132. Xiao Z, Carrasco RA, Schifferli K, Kinneer K, Tammali R, Chen H, Rothstein R, Wetzel L, Yang C, Chowdhury $\mathrm{P}$, Tsui $\mathrm{P}$, Steiner $\mathrm{P}$, Jallal $\mathrm{B}$, et al. A Potent HER3 Monoclonal Antibody That Blocks Both Ligand-Dependent and -Independent Activities: Differential Impacts of PTEN Status on Tumor Response. Mol Cancer Ther. 2016; 15:689-701.

133. Bauer TM, Infante JR, Eder JP, LoRusso P, LaVallee T, Gedrich R, Sidor C, Falchook GS. A phase 1, open-label study to evaluate the safety and pharmacokinetics of the anti ErbB3 antibody, KTN3379, alone or in combination with targeted therapies in patients with advanced tumors. J Clin Oncol. 2015; 33: abstr 2598.

134. Meetze K, Vincent S, Tyler S, Mazsa EK, Delpero AR, Bottega S, McIntosh D, Nicoletti R, Winston WM, Weiler 
S, Feng B, Gyuris J, Weng Z. Neuregulin 1 expression is a predictive biomarker for response to AV-203, an ERBB3 inhibitory antibody, in human tumor models. Clin Cancer Res. 2015; 21:1106-14.

135. Sarantopoulos J, Gordon MS, Harvey RD, Sankhala KK, Malik L, Mahalingam D, Owonikoko TK, Lewis CM, Payumo F, Miller J, Powell C, Weng Z, Komarnitsky PB, et al. First-in-human phase 1 dose-escalation study of AV203, a monoclonal antibody against ERBB3, in patients with metastatic or advanced solid tumors. J Clin Oncol. 2014; 32: abstr 11113.

136. Mirschberger C, Schiller CB, Schräml M, Dimoudis N, Friess T, Gerdes CA, Reiff U, Lifke V, Hoelzlwimmer G, Kolm I, Hopfner KP, Niederfellner G, Bossenmaier B. RG7116, a therapeutic antibody that binds the inactive HER3 receptor and is optimized for immune effector activation. Cancer Res. 2013; 73:5183-94.

137. Meneses-Lorente G, Friess T, Kolm I, Hölzlwimmer G, Bader S, Meille C, Thomas M, Bossenmaier B. Preclinical pharmacokinetics, pharmacodynamics, and efficacy of RG7116: a novel humanized, glycoengineered anti-HER3 antibody. Cancer Chemother Pharmacol. 2015; 75:837-50.

138. Meulendijks D, Jacob W, Martinez-Garcia M, Taus A, Lolkema MP, Voest EE, Langenberg MH, Fleitas Kanonnikoff T, Cervantes A, De Jonge MJ, Sleijfer S, Soerensen MM, Thomas M, et al. First-in-Human Phase I Study of Lumretuzumab, a Glycoengineered Humanized Anti-HER3 Monoclonal Antibody, in Patients with Metastatic or Advanced HER3-Positive Solid Tumors. Clin Cancer Res. 2016; 22:877-85.

139. Wang Q, Zhang X, Shen E, Gao J, Cao F, Wang X, Li Y, Tian T, Wang J, Chen Z, Wang J, Shen L. The anti-HER3 antibody in combination with trastuzumab exerts synergistic antitumor activity in HER2-positive gastric cancer. Cancer Lett. 2016; 380:20-30.

140. Le Clorennec C, Lazrek Y, Dubreuil O, Larbouret C, Poul MA, Mondon P, Melino G, Pèlegrin A, Chardès T. The anti-HER3 (ErbB3) therapeutic antibody 9F7-F11 induces HER3 ubiquitination and degradation in tumors through JNK1/2- dependent ITCH/AIP4 activation. Oncotarget. 2016; 7:37013-29. https://doi.org/10.18632/ oncotarget.9455

141. Bossenmaier B, Friess T, Gerdes C, Kolm I, Dimoudis N, Lifke V, Reiff U, Moessner E, Hoelzlwimmer G, von Hirschheydt T, Burtscher H, Niederfellner G. Abstract 2508: GE-huMab-HER3, a novel humanized, glycoengineered HER3 antibody with enhanced ADCC and superior preclinical in vitro and in vivo efficacy. Cancer Res. 2012; 72:2508-2508.

142. Clarke N, Hopson C, Hahn A, Sully K, Germaschewski F, Yates J, Akinseye C, Mangatt B, Jonak Z, Matheny C. Preclinical pharmacologic characterization of GSK2849330, a monoclonal AccretaMab® antibody with optimized ADCC and CDC activity directed against HER3. Eur J Cancer. 2014; 50:98-99.
143. Sala G, Rapposelli IG, Ghasemi R, Piccolo E, Traini S, Capone E, Rossi C, Pelliccia A, Di Risio A, D’Egidio M, Tinari N, Muraro R, Iacobelli S, and Consorzio Interuniversitario Nazionale per la Bio-Oncologia (CINBO). EV20, a Novel Anti-ErbB-3 Humanized Antibody, Promotes ErbB-3 Down-Regulation and Inhibits Tumor Growth In Vivo. Transl Oncol. 2013; 6:676-84.

144. Capparelli C, Rosenbaum S, Berman-Booty LD, Salhi A, Gaborit N, Zhan T, Chervoneva I, Roszik J, Woodman SE, Davies MA, Setiady YY, Osman I, Yarden Y, Aplin AE. ErbB3-ErbB2 Complexes as a Therapeutic Target in a Subset of Wild-type BRAF/NRAS Cutaneous Melanomas. Cancer Res. 2015; 75:3554-67.

145. Kugel CH 3rd, Hartsough EJ, Davies MA, Setiady YY, Aplin AE. Function-blocking ERBB3 antibody inhibits the adaptive response to RAF inhibitor. Cancer Res. 2014; $74: 4122-32$.

146. Li X, Duan Y, Qiao C, Zhou T, Yu M, Geng J, Feng J, Shen B, Lv M, Li Y. Anti-HER3 Monoclonal Antibody Inhibits Acquired Trastuzumab-Resistant Gynecologic Cancers. Technol Cancer Res Treat. 2016; 15:573-82.

147. Blackburn E, Zona S, Murphy ML, Brown IR, Chan SK, Gullick WJ. A monoclonal antibody to the human HER3 receptor inhibits Neuregulin 1-beta binding and co-operates with Herceptin in inhibiting the growth of breast cancer derived cell lines. Breast Cancer Res Treat. 2012; 134:5359.

148. Poovassery JS, Kang JC, Kim D, Ober RJ, Ward ES. Antibody targeting of HER2/HER3 signaling overcomes heregulin-induced resistance to PI3K inhibition in prostate cancer. Int J Cancer. 2015; 137:267-77.

149. Schaefer G, Haber L, Crocker LM, Shia S, Shao L, Dowbenko D, Totpal K, Wong A, Lee CV, Stawicki S, Clark R, Fields C, Lewis Phillips GD, et al. A two-in-one antibody against HER3 and EGFR has superior inhibitory activity compared with monospecific antibodies. Cancer Cell. 2011; 20:472-86.

150. Huang S, Li C, Armstrong EA, Peet CR, Saker J, Amler LC, Sliwkowski MX, Harari PM. Dual targeting of EGFR and HER3 with MEHD7945A overcomes acquired resistance to EGFR inhibitors and radiation. Cancer Res. 2013; 73:82433.

151. Li C, Huang S, Armstrong EA, Francis DM, Werner LR, Sliwkowski MX, van der Kogel A, Harari PM. Antitumor Effects of MEHD7945A, a Dual-Specific Antibody against EGFR and HER3, in Combination with Radiation in Lung and Head and Neck Cancers. Mol Cancer Ther. 2015; 14:2049-59.

152. Tao JJ, Castel P, Radosevic-Robin N, Elkabets M, Auricchio N, Aceto N, Weitsman G, Barber P, Vojnovic B, Ellis H, Morse N, Viola-Villegas NT, Bosch A, et al. Antagonism of EGFR and HER3 enhances the response to inhibitors of the PI3K-Akt pathway in triple-negative breast cancer. Sci Signal. 2014; 7:ra29.

153. Juric D, Dienstmann R, Cervantes A, Hidalgo M, 
Messersmith W, Blumenschein GR Jr, Tabernero J, Roda D, Calles A, Jimeno A, Wang X, Bohórquez SS, Leddy $\mathrm{C}$, et al. Safety and Pharmacokinetics/Pharmacodynamics of the First-in-Class Dual Action HER3/EGFR Antibody MEHD7945A in locally advanced or metastatic epithelial tumors. Clin Cancer Res. 2015; 21:2462-70.

154. Clement PM, Machiels J, Wirth LJ, Specenier P, Seiwert T, Mardjuadi F, Wang X, Kapp A, Royer-Joo S, Penuel E, McCall B, Pirzkall A, Jimeno A. Phase 1b study of MEHD7945A (MEHD) plus cisplatin/fluorouracil (CIS/5FU) or carboplatin/paclitaxel (Carbo/Pac) for first-line treatment of recurrent/metastatic squamous cell carcinoma of head and neck. Ann Oncol. 2014; 25:iv341.

155. Fayette J, Wirth LJ, Oprean C, Hitt R, Udrea A, Jimeno A, Rischin D, Nutting C, Harari P, Szi TC̈, Cernea D, Wang X, Kapp A, et al. Randomized phase II study of MEHD7945A (MEHD) vs cetuximab (CET) in >=2nd-line recurrent/ metastatic squamous cell carcinoma of the head and neck progressive on/after platinum-based chemotherapy. Ann Oncol. 2014; 25:iv340-56.

156. Hill AG, Findlay M, Burge M, Jackson C, Garcia Alfonso P, Samuel L, Ganju V, Karthaus M, Amatu A, Jeffery M, DiBartolomeo M, Bridgewater J, Coveler A, et al. Abstract CT110: randomized phase II study of duligotuzumab + FOLFIRI versus cetuximab + FOLFIRI in 2nd-line patients with KRAS wild-type (wt) metastatic colorectal cancer (mCRC). Cancer Res. 2015; 75:CT110-110.

157. McDonagh CF, Huhalov A, Harms BD, Adams S, Paragas V, Oyama S, Zhang B, Luus L, Overland R, Nguyen S, Gu J, Kohli N, Wallace M, et al. Antitumor activity of a novel bispecific antibody that targets the ErbB2/ErbB3 oncogenic unit and inhibits heregulin-induced activation of ErbB3. Mol Cancer Ther. 2012; 11:582-93.

158. Richards DA, Braiteh FS, Garcia AA, Conkling CSDPR, Edenfield WJ, Anthony SP, Hellerstedt BA, Raju RN, Becerra C, Harb WA, Smith DA, McDonagh CF, Kawash KL, et al. A phase 1 study of MM-111, a bispecific HER2/ HER3 antibody fusion protein, combined with multiple treatment regimens in patients with advanced HER2positive solid tumors. J Clin Oncol. 2014; 32: abstr 651.

159. Denlinger CS, Maqueda MA, Watkins DJ, Sym SJ, Bendell JC, Park SH, Arkenau HT, Bekaii-Saab TS, Kudla AJ, McDonagh CF, Czibere AG, Chibaudel B, Press MF, et al. Randomized phase 2 study of paclitaxel (PTX), trastuzumab (T) with or without MM-111 in HER2 expressing gastroesophageal cancers (GEC). J Clin Oncol. 2016; 34: abstr 4043.

160. Nahta R, Yuan LX, Zhang B, Kobayashi R, Esteva FJ. Insulin-like growth factor-I receptor/human epidermal growth factor receptor 2 heterodimerization contributes to trastuzumab resistance of breast cancer cells. Cancer Res. 2005; 65:11118-28.

161. Huang F, Greer A, Hurlburt W, Han X, Hafezi R, Wittenberg GM, Reeves K, Chen J, Robinson D, Li A, Lee FY, Gottardis MM, Clark E, et al. The mechanisms of differential sensitivity to an insulin-like growth factor-1 receptor inhibitor (BMS-536924) and rationale for combining with EGFR/HER2 inhibitors. Cancer Res. 2009; 69:161-70.

162. Desbois-Mouthon C, Baron A, Blivet-Van Eggelpoël MJ, Fartoux L, Venot C, Bladt F, Housset C, Rosmorduc O. Insulin-like growth factor-1 receptor inhibition induces a resistance mechanism via the epidermal growth factor receptor/HER3/AKT signaling pathway: rational basis for cotargeting insulin-like growth factor-1 receptor and epidermal growth factor receptor in hepatocellular carcinoma. Clin Cancer Res. 2009; 15:5445-56.

163. Fitzgerald JB, Johnson BW, Baum J, Adams S, Iadevaia S, Tang J, Rimkunas V, Xu L, Kohli N, Rennard R, Razlog M, Jiao Y, Harms BD, et al. MM-141, an IGF-IR- and ErbB3-directed bispecific antibody, overcomes network adaptations that limit activity of IGF-IR inhibitors. Mol Cancer Ther. 2014; 13:410-25.

164. Isakoff SJ, Saleh MN, Lugovskoy A, Mathews S, Czibere AG, Shields AF, Bahleda R, Soria JC, Arnedos M. First-inhuman study of MM-141: A novel tetravalent monoclonal antibody targeting IGF-1R and ErbB3. J Clin Oncol. 2015; 33:384.

165. Zhou BB, Peyton M, He B, Liu C, Girard L, Caudler E, Lo Y, Baribaud F, Mikami I, Reguart N, Yang G, Li Y, Yao W, et al. Targeting ADAM-mediated ligand cleavage to inhibit HER3 and EGFR pathways in non-small cell lung cancer. Cancer Cell. 2006; 10:39-50.

166. Richards FM, Tape CJ, Jodrell DI, Murphy G. Anti-tumour effects of a specific anti-ADAM17 antibody in an ovarian cancer model in vivo. PLoS One. 2012; 7:e40597.

167. Kirkegaard T, Yde CW, Kveiborg M, Lykkesfeldt AE. The broad-spectrum metalloproteinase inhibitor BB-94 inhibits growth, HER3 and Erk activation in fulvestrant-resistant breast cancer cell lines. Int J Oncol. 2014; 45:393-400.

168. Jeschke M, Wels W, Dengler W, Imber R, Stöcklin E, Groner B. Targeted inhibition of tumor-cell growth by recombinant heregulin-toxin fusion proteins. Int J Cancer. 1995; 60:730-39.

169. Landgraf R, Pegram M, Slamon DJ, Eisenberg D. Cytotoxicity and specificity of directed toxins composed of diphtheria toxin and the EGF-like domain of heregulin beta1. Biochemistry. 1998; 37:3220-28.

170. Yang D, Kuan CT, Payne J, Kihara A, Murray A, Wang LM, Alimandi M, Pierce JH, Pastan I, Lippman ME. Recombinant heregulin-Pseudomonas exotoxin fusion proteins: interactions with the heregulin receptors and antitumor activity in vivo. Clin Cancer Res. 1998; 4:9931004.

171. Siegall CB, Bacus SS, Cohen BD, Plowman GD, Mixan B, Chace D, Chin DM, Goetze A, Green JM, Hellström I, Hellström KE, Fell HP. HER4 expression correlates with cytotoxicity directed by a heregulin-toxin fusion protein. $\mathrm{J}$ Biol Chem. 1995; 270:7625-30. 
172. Jay SM, Kurtagic E, Alvarez LM, de Picciotto S, Sanchez E, Hawkins JF, Prince RN, Guerrero Y, Treasure CL, Lee RT, Griffith LG. Engineered bivalent ligands to bias ErbB receptor-mediated signaling and phenotypes. J Biol Chem. 2011; 286:27729-40.

173. Lustgarten J. Anti-Her-2/neu-IL-2 or heregulin-IL-2 fusions proteins redirect non-tumor specific CTL to the tumor site for tumor eradication. Cancer Immunol Immunother. 2003; 52:751-60.

174. Muniappan A, Banapour B, Lebkowski J, Talib S. Ligandmediated cytolysis of tumor cells: use of heregulin-zeta chimeras to redirect cytotoxic T lymphocytes. Cancer Gene Ther. 2000; 7:128-34.

175. Altenschmidt U, Kahl R, Moritz D, Schnierle BS, Gerstmayer B, Wels W, Groner B. Cytolysis of tumor cells expressing the Neu/erbB-2, erbB-3, and erbB-4 receptors by genetically targeted naive $\mathrm{T}$ lymphocytes. Clin Cancer Res. 1996; 2:1001-08.

176. Koziolek EJ, Donoghue JF, Bentley JD, Lovrecz G, Dolezal O, Ward CW, Rothacker J, Nice EC, Burgess AW, Hafner M, Johns TG, Adams TE. A high-affinity ErbB4Fc fusion protein is a potent antagonist of heregulin-mediated receptor activation. Growth Factors. 2012; 30:310-19.

177. Wu Y, Zhang Y, Wang M, Li Q, Qu Z, Shi V, Kraft P, Kim S, Gao Y, Pak J, Youngster S, Horak ID, Greenberger LM. Downregulation of HER3 by a novel antisense oligonucleotide, EZN-3920, improves the antitumor activity of EGFR and HER2 tyrosine kinase inhibitors in animal models. Mol Cancer Ther. 2013; 12:427-37.

178. Papadopoulos KP, Moore KN, Lush R, Desai M, Mahmood S, Beckman RA, Mendell-Harary J. Pharmacokinetics, safety, and tolerability of a new patritumab formulation in patients with advanced, refractory solid tumors. J Clin Oncol. 2015; 33:e14026.

179. Mukai H, Saeki T, Aogi K, Naito Y, Matsubara N, Shigekawa T, Ueda S, Takashima S, Hara F, Yamashita
T, Ohwada S, Sasaki Y. Patritumab plus trastuzumab and paclitaxel in human epidermal growth factor receptor 2-overexpressing metastatic breast cancer. Cancer Sci. 2016; 107:1465-70.

180. Higgins MJ, Doyle C, Paepke S, Azaro A, Martin M, Semiglazov V, Smirnova I, Krasnozhon D, Manikhas A, Harb WA, Panasci LC, Pearlberg J, MacBeath G, et al. A randomized, double-blind phase II trial of exemestane plus MM-121 (a monoclonal antibody targeting ErbB3) or placebo in postmenopausal women with locally advanced or metastatic ER+/PR+, HER2-negative breast cancer. J Clin Oncol. 2014; 32: abstr 587.

181. Takahashi S, Kobayashi T, Tomomatsu J, Ito Y, Oda H, Kajitani T, Kakizume T, Tajima T, Takeuchi H, Maacke H, Esaki T. LJM716 in Japanese patients with head and neck squamous cell carcinoma or HER2-overexpressing breast or gastric cancer. Cancer Chemother Pharmacol. 2017; 79:131-38.

182. Cejalvo J, Fleitas T, Felip E, Mendivil AN, MartinezGarcia M, Taus A. A phase Ib study of lumretuzumab, a glycoengineered monoclonal antibody targeting HER3, in combination with carboplatin and paclitaxel as 1st-line for non-small cell lung cancer of squamous histology. Ann Oncol. 2016; 27:114-35. 